\title{
PRODUTIVIDADE E VIABILIDADE ECONÔMICA DA RECRIA E ENGORDA DE BOVINOS EM PASTAGENS ADUBADAS INTENSIVAMENTE COM E SEM O USO DA IRRIGAÇÃO
}

FÁBIO LUIZ AIRES MAYA

\begin{abstract}
Dissertação apresentada à Escola Superior de Agricultura "Luiz de Queiroz", Universidade de São Paulo, para obtenção do título de Mestre em Agronomia, Área de Concentração: Ciência Animal e Pastagens.
\end{abstract}

\author{
PIRACICABA \\ Estado de São Paulo - Brasil \\ Maio - 2003
}




\title{
PRODUTIVIDADE E VIABILIDADE ECONÔMICA DA RECRIA E ENGORDA DE BOVINOS EM PASTAGENS ADUBADAS INTENSIVAMENTE COM E SEM O USO DA IRRIGAÇÃO
}

\author{
FÁBIO LUIZ AIRES MAYA \\ Engenheiro Agrônomo \\ Orientador: Prof. Dr. MOACYR CORSI \\ Dissertação apresentada à Escola Superior \\ de Agricultura "Luiz de Queiroz", \\ Universidade de São Paulo, para obtenção \\ do título de Mestre em Agronomia, Área de \\ Concentração: Ciência Animal e Pastagens.
}

\author{
PIRACICABA \\ Estado de São Paulo - Brasil \\ Maio- 2003
}




\title{
Dados Internacionais de Catalogação na Publicação (CIP)
} DIVISÃO DE BIBLIOTECA E DOCUMENTAÇÃO - ESALQ/USP

\author{
Maya, Fábio LuizAires \\ Produtivida de e viabilidade econômic a da recria e engorda de \\ bovinos em pasta- gens adubadas intensiva mente com e sem o uso da \\ irigação / Fábio Luiz Aires Maya. - - Piracicaba, 2003. \\ $83 \mathrm{p}$. \\ Dissertação (mestrado) - - Escola Superior de Agricultura Luiz de \\ Queiroz, 2003. \\ Bibliografia. \\ 1. Adubação 2. Bovinos de corte 3. Engorda 4. Irrigação 5. Pastagens 6. \\ Recria 7. Viabilidade econômica I. Título
}

CDD 636.213

"Permitida a cópia total ou parcial deste documento, desde que citada a fonte - $\mathrm{O}$ autor" 
Aos meus pais

Antônio Luiz Maya

e Celni Aires de Abreu Maya

Dedico 


\section{AGRADECIMENTOS}

- Aos meus pais Antônio Luiz Maya e Celni Aires de Abreu Maya pelo constante incentivo.

- Aos meus irmãos Nil e Júnior pelo apoio e compreensão nos momentos difíceis.

- À Bianca Caetano de Almeida pela paciência e companheirismo ao longo do desenvolvimento do trabalho.

- Ao Prof. Dr. Moacyr Corsi pela orientação acadêmica e exemplo de vida pessoal e profissional.

- Aos Eng. Agr. Marco Antônio Penati e Luís Gustavo Barione pelas valiosas sugestões apresentadas ao trabalho.

- Aos colegas de pós-graduação Roberto Naves e Miguel Menezes pela ajuda na condução dos trabalhos de campo.

- Ao Eng. Agr. Sérgio de Zen pelo auxílio e sugestões nas avaliações econômicas.

- A todos os estagiários do Projeto CAPIM sem os quais a execução desse trabalho seria impossível. 


\section{SUMÁRIO}

Página

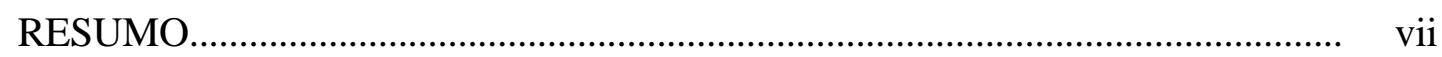

SUMMARY ............................................................................................ ix

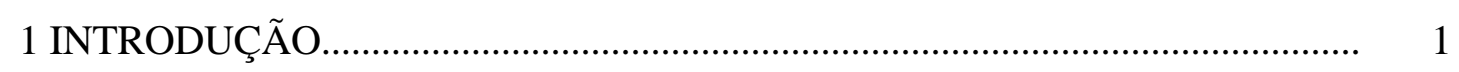

2 REVISÃO DE LITERATURA.................................................................. 4

2.1 Irrigação de plantas forrageiras tropicais................................................................. 4

2.2 Produtividade animal em pastagens adubadas intensivamente para a produção de bovinos de corte.................................................................................................. 5

2.3 Viabilidade econômica da adubação intensiva de pastagens.................................... 9

2.3.1 Resultados econômicos da intensificação da exploração de pastagens................. 9

2.3.2 Indicadores de avaliação econômica................................................................... 11

2.3.3 O risco na atividade pecuária....................................................................... 13

2.3.4 Caracterização dos componentes dos custos de produção da adubação intensiva de pastagens

3 PRODUTIVIDADE DA RECRIA E ENGORDA DE BOVINOS EM PASTAGENS ADUBADAS INTENSIVAMENTE COM E SEM O USO DA IRRIGAÇÃO............. 19

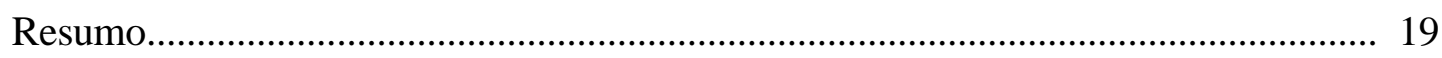

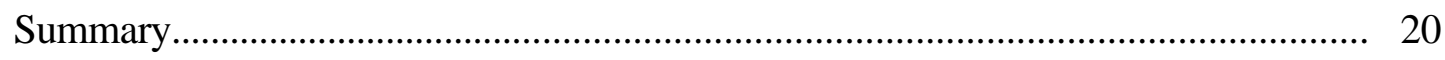

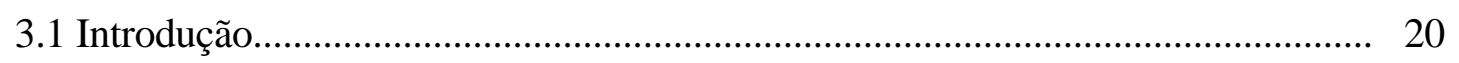

3.2 Material e métodos...................................................................................... 22

3.2.1 Caracterização da área experimental........................................................ 22

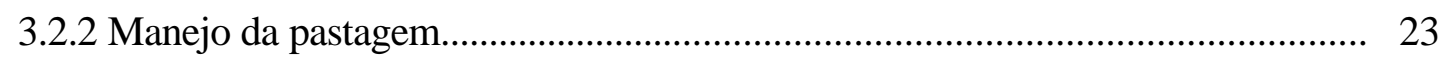

3.2.3 Caracterização e manejo dos animais............................................................. 25

3.2.4 Métodos de avaliação.............................................................................. 26 


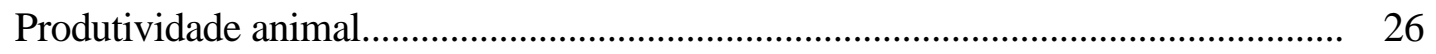

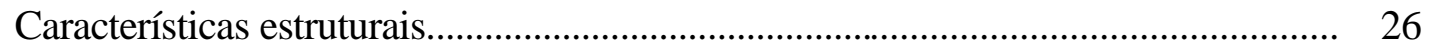

3.2.5 Forma de análise dos resultados.................................................................... 27

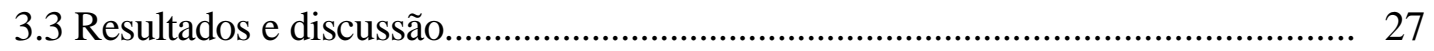

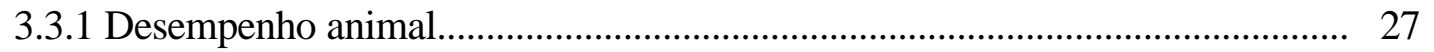

3.3.2 Taxa de lotação............................................................................................. 37

3.3.3 Produtividade animal..................................................................................... 42

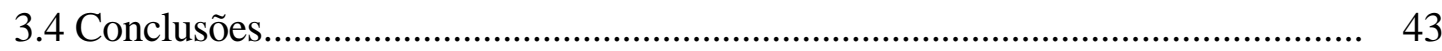

4 VIABILIDADE ECONÔMICA DA RECRIA E ENGORDA DE BOVINOS EM PASTAGENS ADUBADAS INTENSIVAMENTE COM E SEM O USO DA

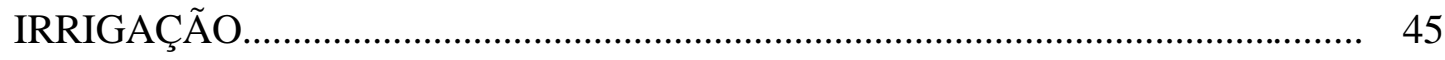

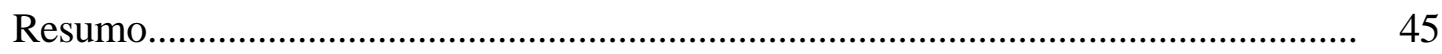

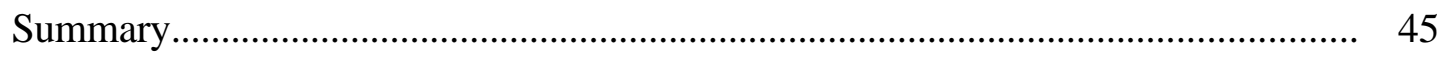

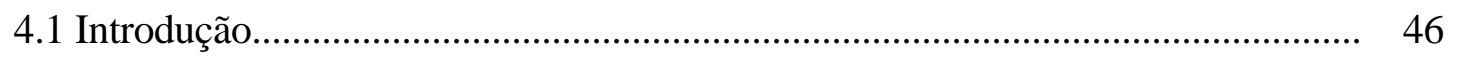

4.2 Material e Métodos....................................................................................... 49

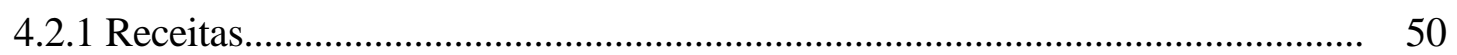

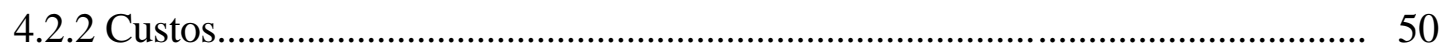

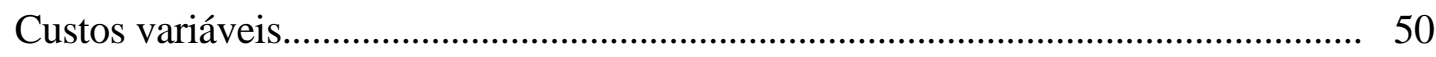

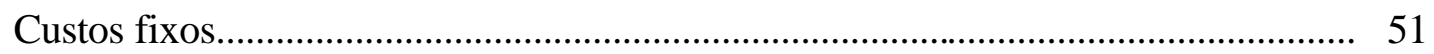

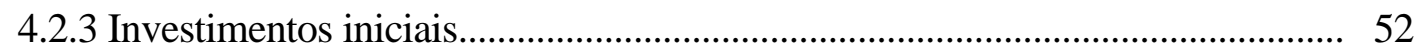

4.2.4 Elaboração do fluxo de caixa.......................................................................... 52

4.2.5 Forma de análise dos resultados...................................................................... 53

4.3 Resultados e discussão..................................................................................... 53

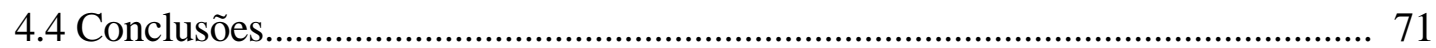

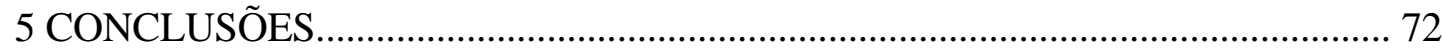

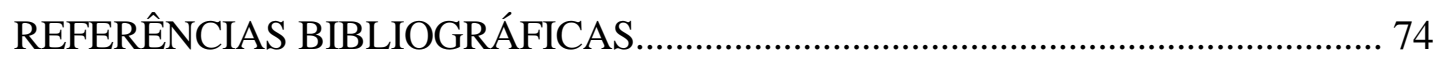




\title{
PRODUTIVIDADE E VIABILIDADE ECONÔMICA DA RECRIA E ENGORDA DE BOVINOS EM PASTAGENS ADUBADAS INTENSIVAMENTE COM E SEM O USO DA IRRIGAÇÃO
}

\author{
Autor: FÁBIO LUIZ AIRES MAYA \\ Orientador: Prof. Dr. MOACYR CORSI
}

\section{RESUMO}

A pecuária de corte extensiva se mostra incapaz de competir em termos de resultados econômicos com outras alternativas de uso da terra em regiões de terras valorizadas, fato que pode ser comprovado pela substituição gradativa de áreas de pastagens por culturas agrícolas. Nessas regiões, a adubação intensiva de pastagens tem se tornado a opção freqüentemente utilizada para o incremento da produtividade animal que é imprescindível para a viabilização econômica da pecuária frente a demais alternativas de uso da terra. A irrigação aliada à adubação de pastagens cresceu muito desde o final da década de 90 no Brasil Central, crescimento motivado pela expectativa de resultados produtivos elevados como os divulgados por revistas técnicas especializadas. Com o intuito de comparar os resultados produtivos e econômicos de pastagens adubadas intensivamente com e sem o uso da irrigação, foram conduzidos dois experimentos ao longo de um ano em pastagens de Panicum maximum cv tanzânia. Foram avaliados desempenho animal, taxa de lotação e produtividade 
nos experimentos. A avaliação econômica foi efetuada com a determinação dos indicadores lucro líquido, taxa de retorno sobre o ativo e taxa interna de retorno, por meio de simulações determinísticas e estocásticas. Enquanto no experimento em sequeiro os valores de desempenho animal e de taxa de lotação médios obtidos foram de 0,615 kg GPD e 5,6 UA/ha, respectivamente, no experimento irrigado foram obtidos $0,492 \mathrm{~kg}$ GPD e 5,9 UA/ha. A irrigação só foi efetiva no incremento da taxa de lotação na transição entre os períodos de "seca" e "águas", não confirmando o potencial da irrigação de pastagens no incremento da taxa de lotação. A diferença de produtividade animal entre os experimentos foi minimizada pelo maior desempenho animal do experimento sem irrigação em alguns períodos. Foram obtidas produtividades de $1.628 \mathrm{~kg}$ $\mathrm{PV} /$ ha no experimento irrigado e $1.672 \mathrm{~kg} \mathrm{PV} / \mathrm{ha}$ no em sequeiro, corroborando o potencial de produtividade de pastagens adubadas intensivamente. A análise de viabilidade sem a consideração de risco apresentou resultados de lucro líquido, taxa de retorno sobre o ativo e taxa interna de retorno, respectivamente de $R \$-164,91$ por hectare, - $1,0 \%$ e $-6,1 \%$, para o sistema irrigado e $R \$$ 574,90 por hectare, 4,4\% e 17,2\% para o em sequeiro. Contudo, essa análise subestimou os resultados dos indicadores de viabilidade econômica em ambos sistemas. A análise de risco apontou o sistema irrigado como inviável economicamente, enquanto para o sistema sem irrigação a probabilidade de um resultado econômico que apontasse inviabilidade foi baixa. 


\title{
PRODUCTIVITY AND ECONOMIC VIABILITY OF BEEF CATTLE PRODUCTION AT HIGHLY FERTILAZED PASTURES WITH AND WITHOUT IRRIGATION
}

\author{
Author: FÁBIO LUIZ AIRES MAYA \\ Adviser: Prof. Dr. MOACYR CORSI
}

\section{SUMMARY}

Extensive beef production cannot compete with others uses of land for agricultural productions, mainly where land costs are high, therefore a gradual substitution of pasture areas for agricultural crops is occurring. High levels of fertilizer application to pastures have been used for improving beef productivity and, consequently, improve the economic profitability of this activity. Irrigation of pasture increased since 90's in Central Brazil, motivated by the expectation of high productivities as presented in technical magazines. The objective of this research was to compare the productivity and economic results of highly fertilized pasture, with and without irrigation. Two experiments were conducted for a year in Panicum maximum cv tanzânia pastures. Weight gain, stocking rate and beef productivity were evaluated. In the economic evaluation was determined net margin, simple rate of return and internal rate of return, using 
deterministic and stochastic simulations. In the non-irrigated experiment the weight gain was $0,615 \mathrm{~kg} /$ day and the stocking rate $5,6 \mathrm{AU} / \mathrm{ha}$, and in the irrigated one, 0,492 kg/day and 5,9 AU/ha, respectively. The irrigation only increased the stocking rate in the season transition between dry and rainy period, not confirming the potential for pasture irrigation in the Central South part of Brazil by increasing stocking rate. Productivity difference in irrigated and nonirrigated pastures was minimized by the high weight gain of non-irrigated area in some periods. The animal live weigh gain was $1.628 \mathrm{~kg} / \mathrm{ha}$ in irrigated experiment, and $1.678 \mathrm{~kg} / \mathrm{ha}$ in non-irrigated one, indicating high potential for $\mathrm{p}$ roductivity of highly fertilized pasture. The analysis without risk consideration showed results of net margin, simple rate of return and internal rate of return, respectively of $R \$-164,91$ per hectare, - 1,0\% and $-6,1 \%$ for irrigated system, and $\mathrm{R} \$ 574,90$ per hectare, $4,4 \%$ and $17,2 \%$ for non-irrigated one. Deterministic analysis sub estimated the results of economic viability indicators. Risk analysis showed weak probability of economic viability for irrigated system. Non-irrigated system with high levels of fertilizer application indicated weak probability for not been an economic activity. 


\section{INTRODUÇÃO}

A vasta área de pastagens, em torno de 177 milhões de hectares segundo o Instituto Brasileiro de Geografia e Estatística (2002), espalhada praticamente por todo o território brasileiro, permite a coexistência de diversos perfis de exploração pecuária em nosso país, desde praticamente extrativistas até altamente tecnificados. Nos últimos anos, contudo, se verificaram pressões crescentes pela intensificação da exploração pecuária, principalmente no Centro-Sul do país, onde as possibilidades de valorização real da terra no horizonte do tempo são remotas e quando existem são de pequena magnitude. Nas fronteiras agrícolas brasileiras, a possibilidade de valorização da terra com a chegada da agricultura na região, acaba por permitir que a pecuária seja desenvolvida de maneira extensiva com resultados econômicos bastante interessantes.

A intensificação diz respeito à implementação na propriedade de qualquer estratégia que em última instância acarrete em aumento da produtividade pecuária. As razões motivadoras da intensificação podem ser agrupadas basicamente em três grupos: razões de ordem social, de ordem econômica e de ordem ambiental.

O aumento do consumo de carne no Brasil nos próximos anos estará na dependência do aumento da renda da população e de seu crescimento vegetativo. A carne bovina é um bem normal, ou seja, apresenta um aumento de consumo decorrente do aumento do poder aquisitivo no estrato de renda até 5 salários mínimos (MB associados, citado por Balsalobre et al., 2002), que compreende cerca de $60 \%$ da população brasileira (IBGE, 2000). Essa informação permite concluir que qualquer incremento no poder aquisitivo da população de mais baixa renda será acompanhado de aumento expressivo no 
consumo de carne bovina e conseqüentemente de uma pressão social grande pelo aumento da produção. Outro fato que contribui para essa pressão é o crescimento vegetativo da população que se mantido em torno de 1,5\% a.a implicará numa população de aproximadamente 200 milhões de habitantes, potenciais consumidores de carne, em 2012 (Balsalobre et al., 2002).

O ritmo crescente das exportações brasileiras de carne bovina, atualmente em torno de 929 mil toneladas de equivalente carcaça (BPS, 2003), também contribui para as pressões sociais pelo aumento da produção, muito embora as exportações sejam responsáveis por apenas $13 \%$ do total comercializado.

Entre 1992 e 2001 a área de pastagens no Estado de São Paulo foi reduzida em 165 mil hectares enquanto as áreas de cana-de-açúcar e de citros cresceram respectivamente 950 mil e 128 mil hectares (Instituto de Economia Agrícola, 1994 e 2002). A substituição de áreas de pastagens por culturas agrícolas mostra a incapacidade da pecuária extensiva competir em termos de resultados econômicos com outras alternativas de uso da terra em regiões de terras valorizadas. Tal fato se constitui numa pressão de ordem econômica pela intensificação da atividade pecuária nessas regiões, onde o custo de oportunidade da terra acaba muitas vezes por inviabilizar a atividade pecuária.

A pecuária de corte é caracteristicamente uma atividade de abertura de fronteiras. Na década de 80 a região de fronteira agrícola nacional era a dos cerrados, na década de 90, entretanto, a fronteira agrícola foi deslocada para a Amazônia Legal, mais precisamente para a região conhecida como "cinturão do desmatamento". Essa região, que compreende os estados do Acre, Rondônia, Norte do Mato Grosso, Sul do Amazonas e do Pará, Tocantins e oeste do Maranhão, é atualmente a maior responsável pelos desmatamentos no Brasil. Levantamentos efetuados por sensoriamento remoto mostraram uma substancial redução no ritmo dos desmatamentos no ano de 2001 (Instituto Brasileiro do Meio Ambiente e dos Recursos Naturais Renováveis, 2002), que embora não possa ser apontada como uma tendência, se constitui em fato 
importante dada a inversão do comportamento crescente dos desmatamentos desde 1997. Parece sensato assumir que grande parte dessas áreas desmatadas tenha se tornado pastagens e dessa forma concluir que o ritmo de crescimento de áreas de pastagens no Brasil esteja diminuindo, em decorrência tanto de pressões ambientais quanto econômicas. De fato, o último senso agropecuário realizado no Brasil (IBGE, 2002), apontou uma redução de 6,6 milhões de hectares na área de pastagens entre 1985 e 1996, indicando claramente que o ritmo de abertura de novas áreas com pastagens é inferior à substituição de áreas de pastagens por culturas agrícolas ou que ao ritmo de regeneração de áreas de matas.

Dentre as estratégias de intensificação da pecuária de corte, esse trabalho se dedicará ao estudo da produtividade e viabilidade econômica da adubação intensiva de pastagens com e sem o uso da irrigação. Desde o final da década de 90, tem-se assistido a um grande crescimento nas áreas de pastagens irrigadas no Brasil Central, motivado pela expectativa de resultados produtivos elevados como os divulgados por revistas técnicas especializadas, 0 que justifica o interesse pela pesquisa dessa modalidade de exploração de pastagens.

O presente trabalho foi estruturado em quatro partes. A primeira foi dedicada àrevisão da literatura relacionada ao tema da dissertação, abordando os tópicos: irrigação de plantas forrageiras tropicais, produtividade em pastagens adubadas intensivamente para a produção de bovinos de corte e viabilidade econômica da exploração intensiva de pastagens. Nas duas partes seguintes foram apresentados trabalhos para publicação: o primeiro relacionado à produtividade de pastagens adubadas intensivamente e o segundo dedicado à análise de viabilidade econômica da adubação intensiva de pastagens. Finalmente, na última seção, foram apresentadas as conclusões gerais da dissertação. 


\section{REVISÃO DE LITERATURA}

\subsection{Irrigação de plantas forrageiras tropicais}

As primeiras pesquisas na área de pastagens irrigadas no Brasil objetivavam verificar o efeito da irrigação na redução da estacionalidade de produção das plantas forrageiras tropicais. Ladeira et al. (1966) verificaram em pastagens de capim pangola (Digitaria decumbens Stent), sempre verde (Panicum maximum) e gordura (Melinis minutiflora Beauv.), irrigadas e adubadas durante o período seco, um incremento médio de $84 \%$ no acúmulo de forragem verde durante esse período. Contudo, pouco efeito foi verificado sobre a estacionalidade de produção, visto que a porcentagem da forragem anual produzida durante o período seco se alterou de $17 \%$ para $23 \%$.

Ghelfi Filho (1972 e 1976) verificaram que a irrigação proporcionava incrementos de $26 \%$ e $44 \%$ no acúmulo de forragem no período "seco" e de $26 \%$ e $22 \%$ no acúmulo das "águas", respectivamente para os capins elefante e colonião, sem que entretanto ocorresse alteração substancial na curva estacional de produção dessas forrageiras, que se mantinha com aproximadamente $24 \%$ da forragem sendo acumulada durante o período seco. Outros autores também verificaram a ausência de resposta à irrigação na alteração da estacionalidade de produção de forrageiras tropicais, demonstrando a existência de fatores outros, que não a deficiência hídrica, como a temperatura e o fotoperíodo, limitando a produção de matéria seca durante o período de inverno (Carvalho et al., 1975; Ghelfi Filho, 1978; Alvim et al., 1986; Alvim et al., 1993; Marcelino et al., 2001).

Os resultados de incrementos no acúmulo de matéria seca durante o período das "águas" em decorrência da irrigação apontam para um potencial de utilização da irrigação de pastagens no Brasil Central durante esse período, 
quando as condições de temperatura e fotoperíodo não são limitantes à produção de forragem e são freqüentes períodos de déficit hídrico ("veranicos") que limitam substancialmente a produção. Nesse sentido, a irrigação de pastagens pode se constituir em prática de manejo com o objetivo de eliminar os efeitos de déficit hídrico durante o "verão" e assim proporcionar maior economicidade no uso elevado de adubações nitrogenadas, necessárias para a exploração do potencial de produção das gramíneas forrageiras tropicais.

Em determinadas regiões, onde as condições de temperatura e fotoperíodo no inverno não são limitantes à produção da planta forrageira, temse verificado, entretanto, respostas consideráveis a irrigação de pastagens durante o período seco. Assim, Maldonado et al. (1997) em Campo dos Goytacazes - RJ, verificaram incremento de $57 \%$ no acúmulo de forragem do período seco quando pastagens de capim elefante napier foram irrigadas, de modo que $52 \%$ da forragem foi produzido no período seco. Vilela et al. (2002), em Minas Gerais, verificaram que a irrigação de pastagens de capim elefante paraíso (Pennisetum hybridum) possibilitava uma produção de forragem seis a sete vezes maior durante o período de outono/inverno. Matsumoto et al. (2002) também obtiveram considerável incremento na produção de forragem, quando cultivares de Panicum (guiné, colonião, mombaça, tanzânia e centauro) foram irrigados em Ilha Solteira - SP, verificando aumento anual de $40 \%$ na forragem produzida. Resultado tão favorável foi atingido devido tanto à eliminação dos "veranicos", comuns no início e final do período de chuvas, quanto devido ao considerável aumento de produção de forragem durante o período seco.

\subsection{Produtividade animal em pastagens adubadas intensivamente para a produção de bovinos de corte}

A produtividade é entendida como a quantidade de produto animal (carne ou leite) produzida por área. Resultante do balanço entre o desempenho animal 
(produção por animal) e a taxa de lotação (número de animais por unidade de área), a produtividade é muitas vezes negligenciada, muito embora seja de vital importância para a viabilização econômica da atividade pecuária frente æ̀ demais alternativas de uso da terra. Dentre os componentes da produtividade, a taxa de lotação tem um maior potencial de alteração da produtividade quando comparada com o desempenho animal, por apresentar maior amplitude de respostas passíveis de serem obtidas.

Pastagens adubadas intensivamente são caracterizadas por elevadas produtividades. Enquanto a produtividade média da exploração extensiva de pastagens gira em torno de $60 \mathrm{~kg} \mathrm{PV/ha*ano} \mathrm{(Arruda,} \mathrm{1997),} \mathrm{o} \mathrm{potencial} \mathrm{de}$ pastagens adubadas intensivamente está entre 1600 e $2000 \mathrm{~kg} \mathrm{PV/ha*ano}$ (Corsi \& Santos, 1995). Contudo, a existência de resultados recentes na literatura nos quais esse potencial foi atingido, apontam para a possibilidade de que o mesmo possa ser superado em breve.

Embora seja adotada por reduzida porcentagem das propriedades pecuárias brasileiras ${ }^{1}$, a intensificação da exploração de pastagens não é algo recente. Chandler (1973), em Porto Rico, obteve produtividade de $1.319 \mathrm{~kg}$ PV/ha*ano, em pastagens de capim guiné (Panicum maximum Jacq.) adubadas com $350 \mathrm{~kg}$ de N/ha*ano. Tal adubação permitiu desempenho animal de 0,6 kg GPD e taxa de lotação média de 3,9 UA/ha. Já Caro-Costas (1980), também em Porto Rico, com pastagens de guiné adubadas com $336 \mathrm{~kg} \mathrm{~N} / \mathrm{ha}{ }^{*}$ ano obteve $844 \mathrm{~kg} \mathrm{PV/ha}$ *ano, com taxa de lotação e desempenho animal respectivamente de 2,7 UA/ha e 0,47 kg GPD. As diferenças entre os resultados obtidos pelos dois autores, mesmo com níveis de adubação nitrogenada semelhantes, são decorrentes das condições climáticas e de fertilidade do solo de cada um dos experimentos.

\footnotetext{
${ }^{1}$ No estado de São Paulo, tido como o de pecuária mais desenvolvida no Brasil, somente $15,7 \%$ da área de pastagens é explorada intensivamente (CATI, 1999).
} 
$\mathrm{Na}$ literatura nacional, os resultados produtivos de pastagens manejadas intensivamente são mais recentes e podem ser observados na tabela 1 . Verifica-se uma grande amplitude de variação nos resultados, justificável por diferenças relativas à condição climática, categoria animal, raça animal e forrageira utilizadas, além do manejo diferenciado imposto em cada trabalho. A comparação entre esses deve ser feita então com ressalvas, visto que além da interferência dos fatores supracitados no resultado produtivo, a duração dos períodos de "águas" e "seca" também não é a mesma para os experimentos. Contudo, observa-se que os níveis da adubação nitrogenada dos trabalhos são cada vez maiores e acompanhados de resultados produtivos também crescentes. Esse fato demonstra a preocupação com a elevação da produtividade pecuária em regiões de terras caras como nas que foram desenvolvidos os experimentos. 
Tabela 1. Resultados produtivos de pastagens adubadas intensivamente sem 0 uso de irrigação existentes na literatura nacional.

\begin{tabular}{|c|c|c|c|c|c|c|c|c|c|c|}
\hline \multirow[t]{2}{*}{ Referência } & \multicolumn{2}{|c|}{$\begin{array}{l}\text { Produtividade } \\
\text { (kg PV/ha) }\end{array}$} & \multicolumn{2}{|c|}{$\begin{array}{l}\text { Taxa } \\
\text { lotação } \\
\text { (UA/ha) }\end{array}$} & \multicolumn{2}{|c|}{$\begin{array}{c}\text { Desempenho } \\
\text { animal } \\
\text { (kg GPD) }\end{array}$} & \multirow[t]{2}{*}{$\begin{array}{l}\text { Categoria } \\
\text { e raça } \\
\text { animal }\end{array}$} & \multirow[t]{2}{*}{ Forrageira } & \multirow[t]{2}{*}{$\begin{array}{c}\text { Adubação } \\
\text { N } \\
\text { (kg/ha) }\end{array}$} & \multirow[t]{2}{*}{ Local } \\
\hline & $A^{1}$ & $S^{2}$ & A & $S$ & A & $S$ & & & & \\
\hline $\begin{array}{l}\text { Corrēa } \\
\text { (1999) }\end{array}$ & 1.181 & - & 5,8 & - & 0,68 & - & $\begin{array}{l}\text { Novilhas } \\
\text { canchim }\end{array}$ & tanzânia & 200 & $\begin{array}{c}\text { São } \\
\text { Carlos } \\
\text { SP }\end{array}$ \\
\hline $\begin{array}{l}\text { Corrêa } \\
\text { (1999) }\end{array}$ & - & - & 6,4 & - & 0,82 & - & $\begin{array}{l}\text { Novilhos } \\
\text { canchim }\end{array}$ & tanzânia & 300 & $\begin{array}{l}\text { São } \\
\text { Carlos } \\
\text { SP }\end{array}$ \\
\hline $\begin{array}{c}\text { Tosi } \\
\text { (1999) }\end{array}$ & 910 & 460 & 6,6 & 2,7 & 0,82 & 0,53 & $\begin{array}{l}\text { Novilhos } \\
\text { canchim }\end{array}$ & tanzânia & 320 & $\begin{array}{l}\text { São } \\
\text { Carlos } \\
\text { SP }\end{array}$ \\
\hline $\begin{array}{l}\text { Aguiar et al. } \\
\text { (2001b) }\end{array}$ & 797 & 381 & 5,3 & 2,0 & 0,72 & 0,64 & $\begin{array}{l}\text { Garrotes } \\
\text { cruzamento } \\
\text { industrial }\end{array}$ & tanzânia & 340 & $\begin{array}{c}\text { Uberaba } \\
\text { MG }\end{array}$ \\
\hline $\begin{array}{l}\text { Aguiar et al. } \\
\text { (2001b) }\end{array}$ & 936 & 353 & 6,4 & 2,4 & 0,70 & 0,51 & $\begin{array}{l}\text { Garrotes } \\
\text { cruzamento } \\
\text { industrial }\end{array}$ & mombaça & 340 & $\begin{array}{c}\text { Uberaba } \\
\text { MG }\end{array}$ \\
\hline $\begin{array}{l}\text { Lugão } \\
\text { (2001) }\end{array}$ & 1.713 & - & 10 & - & 0,66 & - & $\begin{array}{c}\text { Garrotes } \\
\text { cruzamento } \\
\text { industrial }\end{array}$ & $\begin{array}{l}\text { BRA - } \\
006998\end{array}$ & 450 & $\begin{array}{c}\text { Paranavaí } \\
\text { PR }\end{array}$ \\
\hline $\begin{array}{l}\text { Aguiar et al. } \\
\text { (2002a) }\end{array}$ & 1.590 & - & 7,2 & - & 0,65 & - & $\begin{array}{c}\text { Garrotes } \\
\text { cruzamento } \\
\text { industrial }\end{array}$ & tanzânia & 533 & $\begin{array}{c}\text { Uberaba } \\
\text { MG }\end{array}$ \\
\hline $\begin{array}{l}\text { Aguiar et al. } \\
\text { (2002a) }\end{array}$ & 1.410 & - & 7,0 & - & 0,72 & - & $\begin{array}{c}\text { Garrotes } \\
\text { cruzamento } \\
\text { industrial }\end{array}$ & mombaça & 523 & $\begin{array}{c}\text { Uberaba } \\
\text { MG }\end{array}$ \\
\hline
\end{tabular}


A abundância de trabalhos relatando a produtividade de pastagens adubadas intensivamente sem irrigação, contrasta com a escassez de trabalhos relativos a produtividade de pastagens irrigadas. A maior parte dos resultados existentes é encontrada em publicações técnicas, sendo raros os resultados provenientes de trabalhos científicos. Dentre os existentes até o momento, ainda não se tem confirmação do real potencial das pastagens tropicais irrigadas na obtenção de elevadas taxas de lotação e produtividades.

Avaliando o desempenho do capim mombaça sob irrigação no inverno e primavera (115 dias), Müller (2000) obteve, com adubação nitrogenada de 75 $\mathrm{kg} \mathrm{N} / \mathrm{ha}$, taxa de lotação de $6 \mathrm{UA} / \mathrm{ha}$, com produtividade de $576 \mathrm{~kg} \mathrm{PV/ha.} \mathrm{O}$ desempenho animal foi variável em função das diversas categorias animais avaliadas (bezerros anelorados e cruzados desmamados, matrizes solteiras, vacas com bezerro ao pé, bezerros em aleitamento e novilhas).

Penati (2002) com pastagens de capim tanzânia irrigadas e adubadas com $960 \mathrm{~kg} \mathrm{~N} / \mathrm{ha}$, alcançou $1.518 \mathrm{~kg} \mathrm{PV/ha}$ durante o período de novembro de 1999 a dezembro de 2000. A taxa de lotação obtida foi de 6,5 UA/ha e o desempenho animal de $0,40 \mathrm{~kg}$ GPD. A baixa produtividade obtida em relação ao nível de adubação nitrogenada utilizada foi decorrente da reduzida idade da pastagem (implantada em março de 1999), que, por se encontrar ainda em processo de estabilização, acabou por apresentar elevadas perdas de material verde por pastejo no início do período experimental.

\subsection{Viabilidade econômica da adubação intensiva de pastagens}

\subsubsection{Resultados econômicos da intensificação da exploração de pastagens}

Enquanto a viabilidade técnica da intensificação da exploração de pastagens é algo tido como praticamente consolidado, questionamentos quanto 
sua viabilidade econômica existem desde longa data, muito embora comparações econômicas entre sistemas intensivos e extensivos tenham apontado para resultados muito superiores para os primeiros (Esteves, 2000). As respostas econômicas ao uso da intensificação se mostram variáveis, como se pode esperar tendo em vista a ampla gama de fatores envolvidos na determinação do resultado econômico final.

Gomide (1984) concluiu com base em experimentos de curva de resposta à adubação nitrogenada, não ser viável a adubação com nitrogênio (100 kg/ha) em pastagens destinadas à engorda de novilhos, considerando os preços desse insumo e da arroba do boi gordo vigentes na época. Resultados mais recentes, entretanto, demonstram a elevada economicidade do uso de adubação nitrogenada em pastagens. Tosi (1999) obteve lucro líquido de U\$\$ 530 (US $\$ 1=\mathrm{R} \$ 1,07$ ) por hectare na recria e engorda de novilhos canchim em pastagens de capim tanzânia adubadas com $320 \mathrm{~kg} \mathrm{~N} / \mathrm{ha}$ ano. Esteves (2000) obteve lucro líquido por hectare de $R \$ 445,50 \mathrm{com}$ a utilização de $300 \mathrm{~kg}$ $\mathrm{N} /$ ha*ano também em pastagens de capim tanzânia destinadas à recria e engorda de novilhos. Aguiar et al. (2001a) obtiveram lucro líquido de $\mathrm{R} \$ 425,00$ por hectare, quando pastagens de capim tanzânia foram adubadas com $360 \mathrm{~kg}$ N/ha.

O nível de adubação nitrogenada que maximiza o resultado econômico também vem sendo questionado pela pesquisa. Salles \& Gonçalves (1982) concluíram que para pastagens de capim pangola e os preços vigentes em 1981 (relação entre o custo do $\mathrm{kg}$ de $\mathrm{N}$ e o custo do $\mathrm{kg}$ do boi vivo de 1,36 e entre o custo do $\mathrm{kg}$ de $\mathrm{N}$ e 0 litro do leite de 5,1), o nível de adubação nitrogenada de máxima eficiência econômica seria de $157 \mathrm{~kg} \mathrm{~N} / \mathrm{ha}$ para a engorda de bovinos e $249 \mathrm{~kg} \mathrm{~N} / \mathrm{ha}$ para a produção de leite. Lugão (2001), avaliando a resposta de Panicum maximum (acesso BRA - 006998) a diferentes níveis de adubação nitrogenada (0, 150, 300 e $450 \mathrm{~kg} \mathrm{~N} / \mathrm{ha}$ ) durante o período das águas, obteve máximo lucro por hectare $(R \$ 550,00)$ com $419 \mathrm{~kg}$ N/ha. 
Os resultados econômicos da irrigação como estratégia de intensificação do uso de pastagens ainda são escassos. Pinheiro (2002), através de modelos de simulação, obteve, para diferentes regiões do país, os resultados econômicos esperados com a intensificação em pastagens irrigadas e em sequeiro. A máxima taxa interna de retorno com a irrigação $(9,37 \%)$ foi obtida na região de Porto Nacional - TO, sendo de $12,40 \%$ a taxa correspondente à pastagem de sequeiro nessa mesma região.

\subsubsection{Indicadores de avaliação econômica}

Inúmeros indicadores de avaliação econômica têm sido utilizados com o objetivo de comparar os resultados obtidos em sistemas de produção agropecuários. Todos apresentam vantagens e limitações, sendo que cada índice se presta melhor para determinada finalidade do ponto de vista da administração financeira, o que faz com que, para melhores resultados, deva-se efetuar o exame conjunto de diferentes indicadores. Para informações mais profundas a cerca das vantagens e limitações de cada indicador, recomenda-se a leitura de Noronha (1981) e Azevedo Filho (1988).

A taxa de retorno sobre $o$ ativo, também conhecida como taxa de retorno contábil, taxa de retorno simples ou retorno sobre o investimento, é definida como a razão entre a receita líquida e o capital investido (Noronha, 1981; Ross et al. 1998). Do ponto de vista prático fornece a quantidade de vezes que o lucro líquido cobre por ano o investimento total realizado (Hirschfeld, 1993). Suas vantagens advêm da facilidade de cálculo, da possibilidade de comparação entre empreendimentos e entre anos e do uso generalizado na atividade agropecuária. Suas limitações por sua vez, são relacionadas à não consideração do valor do dinheiro no tempo e à impossibilidade de comparações com o custo de oportunidade do capital (Noronha, 1981; Mattos, 1999). 
O valor presente líquido é calculado pela Eq. 1. Gerado com base no fluxo de caixa de um empreendimento, é entendido como a diferença entre o valor de mercado de um investimento e seu custo, levando em consideração o custo de oportunidade do capital (Ross et al., 1998). Por considerar o valor do dinheiro no tempo, permite a comparação direta com outras alternativas de uso do capital (Boehlje \& Eidman, 1984). Como desvantagens apresenta a sensibilidade com relação à duração do projeto e à taxa de desconto, além da dificuldade de interpretação.

$$
V P L=\sum_{i=0}^{n} \frac{(B i-C i)}{(1+j)^{i}}
$$

Onde:

- $\mathrm{Bi} \rightarrow$ fluxo de benefícios;

- $\mathrm{Ci} \rightarrow$ fluxo de custos;

- j $\rightarrow$ taxa de juros considerada;

- $n \rightarrow$ número de períodos do projeto.

A taxa interna de retorno é a taxa de desconto que zera o valor presente líquido de uma série de fluxos de caixa (Eq. 2). É um indicador especialmente útil quando se fazem investimentos iniciais elevados e que contribuem para a produção por vários períodos de tempo, como é comum em empreendimentos pecuários. Apresenta como vantagem principal permitir a comparação direta com o custo do capital ou com alternativas de aplicação no mercado financeiro, além de ser independente de informações exógenas para seu cálculo (Noronha, 1981; Boehlje \& Eidman, 1984; Azevedo Filho, 1988).

$$
T I R=j, \text { tal que } \sum_{i=0}^{n} \frac{(B i-C i)}{(1+j)^{i}}=0
$$

Onde:

- $j \rightarrow$ taxa de desconto; 
- $\mathrm{Bi} \rightarrow$ fluxo de benefícios;

- $\quad \mathrm{Ci} \rightarrow$ fluxo de custos;

- $\mathrm{n} \rightarrow$ número de períodos do projeto.

O período para o pagamento do investimento ("pay-back" econômico) fornece o tempo ou número de anos necessários para a recuperação dos investimentos efetuados num dado sistema de produção, levando-se em consideração a dimensão do dinheiro no tempo (Boehlje \& Eidman, 1984; Azevedo Filho, 1988). Calculado com a Eq. 3, trata-se de uma medida de liquidez e não de lucratividade do empreendimento.

$$
P B E=k \text {, tal que } \sum_{i=0}^{k} \frac{F i}{(1+j)^{i}} \geq 0 \quad e \sum_{i=0}^{k-1} \frac{F i}{(1+j)^{i}}<0
$$

Onde:

- $\quad \mathrm{Fi} \rightarrow$ fluxo de caixa no ano i;

- $\quad \mathrm{j} \rightarrow$ taxa de juros considerada;

- $k \rightarrow$ número de períodos.

\subsubsection{O risco na atividade pecuária}

Embora a determinação dos indicadores de viabilidade seja de vital importância para a avaliação econômica de investimentos, é inegável que esses sempre estão sujeitos a incertezas que podem alterar o resultado econômico final previsto. Knight (1972) caracterizou as situações de tomada de decisão em situações de risco e de incerteza. Nas de risco, o tomador de decisão conheceria tanto as respostas possíveis de serem obtidas, quanto as probabilidades de ocorrência de cada uma delas, enquanto nas de incerteza 0 tomador de decisão teria pouca informação a cerca dessas variáveis.

Boehlje \& Eidman (1984) dividem os riscos envolvidos na atividade agropecuária em duas classes: risco do negócio e risco financeiro. Os riscos de negócio são definidos como as incertezas existentes em um empreendimento, 
independente da forma como esse é financiado, enquanto os riscos financeiros estão associados à variação no resultado econômico resultante das possibilidades existentes para o seu financiamento. Quanto aos riscos de negócio, as maiores fontes de variação no resultado econômico são os riscos de preço e riscos de produção. Todos os fatores que acarretam numa imprevisibilidade na oferta e demanda dos insumos e dos produtos finais, causando conseqüente variação nos seus valores monetários, são fontes de risco de preço. As variações no nível de produção resultantes de fatores não controláveis, como clima, pragas e variações genéticas, são as fontes de risco de produção.

O pecuarista nunca tem o conhecimento completo da relação entre os fatores de produção e a produtividade e sobre os preços envolvidos na tomada de decisão. Assim, análises de risco são instrumentos imprescindíveis na avaliação econômica, possibilitando uma estimativa numérica dos riscos envolvidos numa modalidade de exploração.

Dentre as alternativas de análise de risco, a análise de sensibilidade é usada para estimar o efeito que uma alteração específica de preço, nível de produção, custo de oportunidade do capital, ou combinações entre esses fatores, causa no resultado econômico final. A sensibilidade a essas variáveis pode ser expressa tanto em termos de variações absolutas como relativas no valor das variáveis independentes (aquelas modificáveis no fluxo de caixa). Estrada \& Paladines (1979) avaliaram por meio de análise de sensibilidade as variações na taxa interna de retorno de sistemas de produção de bovinos de corte em pastagens irrigadas com diferentes graus de intensificação. Como variáveis relativas foram analisadas as relações entre o preço do fertilizante nitrogenado e o preço dos animais acabados e entre o preço dos animais de reposição e o preço dos animais acabados. Como variáveis absolutas foram analisados o preço da terra e sua possibilidade de valorização no horizonte do tempo, variáveis essas que se mostraram de efeito marcante sobre a taxa interna de retorno da atividade. 
Outra possibilidade no uso da análise de sensibilidade é a da determinação do ponto crítico ("swiching value") para determinadas variáveis, que é o valor da variável independente que modifica a decisão de investir num dado fator (Noronha, 1981). Salles \& Gonçalves (1982) determinaram que o ponto crítico que inviabilizava a utilização de adubação nitrogenada em pastagens de capim pangola se dava numa relação de 2,6 entre o preço do $\mathrm{kg}$ de $\mathrm{N}$ e o preço de kg de PV para a pecuária de corte e de 20,8 entre o preço do kg de $\mathrm{N}$ e o preço do litro de leite na pecuária leiteira.

A análise de sensibilidade é um método rápido e conveniente de determinar o impacto aproximado, que uma alteração de uma ou mais variáveis tem no resultado econômico, daí a sua freqüente escolha como método de análise de risco na avaliação da atividade pecuária (Estrada \& Paladines, 1979; Salles \& Gonçalves, 1982; Euclides et al., 2001; Balsalobre et al., 2002). Contudo, a indicação pura e simples de que um empreendimento é ou não sensível a certas variáveis é de pouca importância quando não se conhece a probabilidade de ocorrência de cada valor analisado dentro de uma dada variável. Nesse sentido, técnicas de simulação devem ser utilizadas na análise de risco quando se pretende dar um tratamento mais elaborado àanálise de um investimento.

O uso de técnicas de simulação objetiva obter uma representação realista da resposta de um sistema a uma dada variável. Essa variável pode apresentar ocorrência determinística ou estocástica, o que implicará no uso de diferentes técnicas de simulação. Nas simulações através de modelos determinísticos, o resultado final depende apenas dos parâmetros de entrada, assumindo assim apenas um valor. Nas simulações através de modelos estocásticos, são introduzidas variáveis aleatórias, de modo que o resultado final é diferente a cada simulação, não se verificando apenas um valor, mas uma distribuição de freqüência (Frizzone, 1999).

Técnicas de simulação vêm sendo utilizadas em análises de risco relacionadas ao risco de preço de diferentes atividades agropecuárias: 
confinamento de bovinos de corte (Peres \& Mattos, 1990; Barione, 2002); citricultura (Azevedo Filho, 1988; Brunelli, 1990); e heveicultura (Takitane, 1988). A simulação permite ainda a previsão de fenômenos meteorológicos os quais são fontes de risco de produção (Sousa, 1999). A utilização de técnicas de simulação permite uma análise realmente abrangente dos possíveis resultados econômicos de um sistema de produção quando se combinam as duas possibilidades, a análise dos riscos de preço e de produção (Andrade Júnior, 2000; Souza, 2001).

\subsubsection{Caracterização dos componentes dos custos de produção da adubação intensiva de pastagens}

Por serem utilizados com finalidades distintas por diferentes agentes econômicos, os estudos de custos de produção são alvos de inúmeras controvérsias. Assim, a definição dos principais componentes dos custos de produção da exploração intensiva de pastagens se torna importante, a fim de que se possa homogeneizar conceitos e assim melhorar a compreensão das informações.

Segundo Turra (1990), a estrutura dos custos de produção determinada através do método convencional, divide os componentes do custo em fixos e variáveis. Enquanto os custos fixos referem-se às despesas que a empresa é obrigada a pagar aos fatores de produção independentemente da quantidade produzida, os custos variáveis dependem diretamente dessa quantidade.

Os principais componentes dos custos fixos são:

- Depreciação: consiste numa reserva contábil destinada a gerar fundos para a substituição do capital investido em bens produtivos de longa duração (Noronha, 1981). Na exploração intensiva de pastagens devem apresentar custos relativos àdepreciação: implantação de pastagens, cercas, bebedouros, cochos de sal e equipamentos de irrigação, quando esses existirem. 
- Juros sobre o capital investido em fatores fixos de produção: representam a remuneração dos bens de produção de longa duração em função do custo de oportunidade do capital, que é entendido como o seu valor no melhor uso alternativo. Além dos itens já citados como passíveis de depreciação, também deve ser remunerado o capital investido em terra. Nesse sentido, Turra (1990) apresenta diversos métodos de cálculo do custo de oportunidade do capital para terra e para demais ativos fixos. Quanto ao juro sobre o capital investido no equipamento de irrigação, sugere-se a metodologia de cálculo proposta por Franke \& Dorfman (1998).

- Mão-de-obra fixa: despesas efetuadas para remuneração dos trabalhadores permanentes incluindo encargos sociais.

- Seguros, taxas e impostos.

Os principais componentes dos custos variáveis incidentes sobre a exploração intensiva de pastagens são: despesas com operações mecanizadas; manutenção de benfeitorias e equipamentos (cercas, bebedouros, equipamentos de irrigação); compra de animais; despesas com insumos (fertilizantes, suplementos, medicamentos, vacinas e vermífugos); energia elétrica (principalmente na irrigação de pastagens); mão-de-obra temporária; e assistência técnica.

As despesas referentes aos gastos com energia elétrica em equipamentos de irrigação podem ser calculadas através de equações como as propostas por Melo (1993) e Frank \& Dorfman (1998). O custo de manutenção de equipamentos de irrigação pode variar de 1,1 a $5 \%$ a.a. do valor de investimento inicial (Soler et al., 1999; Souza, 2001).

De grande impacto nos custos de produção, o custo de implantação de um equipamento de irrigação responde principalmente a variações na vazão total e no comprimento da adutora por unidade de área (Melo, 1993). Embora se reconheça a grande variação possível nos custos de equipamentos de pivô central (método de irrigação de utilização mais freqüente em pastagens 
irrigadas), a título de ilustração são apresentados na tabela 2 custos médios de implantação desse sistema de irrigação, considerando diferentes estratos de áreas.

Tabela 2. Custos médios por hectare ${ }^{1}$ (considerando o pivô central, motobomba, adutora e cabos elétricos) de sistemas de irrigação por pivô central considerando diferentes estratos de áreas.

\begin{tabular}{cc}
\hline Estratos & $\boldsymbol{R} \mathbf{S} \mathbf{h a}$ \\
\hline$<12$ & $6.064,81$ \\
12 a 25 & $4.876,46$ \\
25 a 40 & $3.170,79$ \\
40 a 55 & $2.751,15$ \\
55 a 70 & $2.554,00$ \\
70 a 85 & $2.293,53$ \\
85 a 100 & $2.266,40$ \\
100 a 115 & $2.239,27$ \\
115 a 130 & $2.212,12$ \\
$>130$ & $2.188,62$ \\
\hline
\end{tabular}

${ }^{1}$ Custos de janeiro de 1997 atualizados para dezembro de 2001 com base no IGP-FGV.

Fonte: Souza (2001). 


\section{PRODUTIVIDADE DA RECRIA E ENGORDA DE BOVINOS EM PASTAGENS ADUBADAS INTENSIVAMENTE COM E SEM O USO DA IRRIGAÇÃO}

\section{Resumo}

Durante um ano, foram conduzidos dois experimentos, um irrigado e outro sem irrigação, com o intuito de comparar os resultados de produtividade animal em pastagens de Panicum maximum cv tanzânia adubadas intensivamente. Houve interação entre experimento e período para as variáveis desempenho animal e taxa de lotação. Enquanto no experimento em sequeiro os valores de desempenho animal e de taxa de lotação médios obtidos foram de 0,615 kg GPD e 5,6 UA/ha, respectivamente, no experimento irrigado foram obtidos 0,492 kg GPD e 5,9 UA/ha. A irrigação só foi efetiva no incremento da taxa de lotação na transição entre os períodos de "seca" e "águas", não confirmando o potencial da irrigação de pastagens no incremento da taxa de lotação. A diferença de produtividade animal entre os experimentos foi minimizada pelo maior desempenho animal do experimento sem irrigação em alguns períodos. As produtividades obtidas, $1.628 \mathrm{~kg}$ PV/ha no experimento irrigado e $1.672 \mathrm{~kg} \mathrm{PV/ha}$ no em sequeiro, corroboram o potencial de produtividade de pastagens adubadas intensivamente. 


\section{Summary}

Two experiments, one irrigated and other non-irrigated, were conducted for a year in Panicum maximum cv tanzânia pastures to compare the productivity of highly fertilized pastures. There were interactions among experiment and period for weight gain and stocking rate. In the non-irrigated experiment the weight gain was $0,615 \mathrm{~kg} /$ day and the stocking rate 5,6 $\mathrm{AU} / \mathrm{ha}$, and in the irrigated one, 0,492 kg/day and 5,9 AU/ha, respectively. The irrigation only increased the stocking rate in the season transition between dry and rainy period, not confirming the potential for pasture irrigation in the Central South part of Brazil by increasing stocking rate. Productivity difference in irrigated and nonirrigated pastures was minimized by the high weight gain of non-irrigated area in some periods. The animal live weigh gain was $1.628 \mathrm{~kg} / \mathrm{ha}$ in irrigated experiment, and $1.678 \mathrm{~kg} / \mathrm{ha}$ in non-irrigated one, indicating high potential for productivity of highly fertilized pasture.

\subsection{Introdução}

A produtividade é definida como a quantidade de produto animal (carne ou leite) produzida por área. Resultante do balanço entre o desempenho animal (produção por animal) e a taxa de lotação (número de animais por unidade de área), a produtividade é muitas vezes negligenciada, muito embora seja de vital importância para a viabilização econômica da atividade pecuária frente a demais alternativas de uso da terra. Enquanto a produtividade média da exploração pecuária extensiva gira em torno de $60 \mathrm{~kg}$ PV/ha*ano (Arruda, 1997), o potencial de pastagens adubadas intensivamente é muito superior, estando segundo Corsi \& Santos (1995) entre 1600 e 2000 kg PV/ha*ano.

Embora seja adotada por reduzida porcentagem das propriedades pecuárias brasileiras, a adubação intensiva de pastagens não é uma técnica recente. Chandler (1973), em Porto Rico, obteve produtividade de 1.319 kg 
PV/ha*ano, em pastagens de capim guiné (Panicum maximum Jacq.) adubadas com $350 \mathrm{~kg}$ de N/ha. Tal adubação permitiu desempenho animal de 0,6 kg GPD e taxa de lotação média de 3,9 UA/ha.

$\mathrm{Na}$ literatura nacional, os resultados produtivos de pastagens adubadas intensivamente são mais recentes, sendo esses referentes em sua maioria à adubação sem o uso da irrigação. Tosi (1999), em São Carlos - SP, trabalhando capim tanzânia adubado com $320 \mathrm{~kg} \mathrm{~N} / \mathrm{ha}^{*}$ ano, obteve produtividade de $1.370 \mathrm{~kg} \mathrm{PV} / \mathrm{ha}^{*}$ ano, com taxa de lotação de 4,8 UA/ha e desempenho animal de $0,65 \mathrm{~kg}$ GPD.

Em pastagens de capim tanzânia adubadas com $340 \mathrm{~kg} \mathrm{~N} / \mathrm{ha}^{*}$ ano, Aguiar et al. (2001b), em Uberaba - MG, alcançaram produtividade anual de $1.178 \mathrm{~kg} \mathrm{PV} / \mathrm{ha}$, com taxa de lotação de 3,65 UA/ha e desempenho animal de $0,68 \mathrm{~kg}$ GPD. No mesmo trabalho, mas com pastagens de capim mombaça (Panicum maximum Jacq.) foi alcançada produtividade de $1.289 \mathrm{~kg} \mathrm{PV/ha}{ }^{*}$ ano, com taxa de lotação de 4,4 UA/ha e desempenho animal de 0,60 kg GPD.

Produtividade mais elevada foi obtida por Lugão (2001), no oeste do Paraná, em pastagens de Panicum maximum Jacq. (acesso BRA-006998). Avaliando a resposta produtiva dessa planta forrageira a diferentes níveis de adubação nitrogenada (0,150, 300 e $450 \mathrm{~kg} \mathrm{~N} / \mathrm{ha}$ ) durante o período das águas (200 dias) com garrotes cruzados (nelore $x$ marchigiana, nelore $x$ simental, nelore $\mathrm{x}$ red angus) essa autora obteve máxima produtividade com a dose de $450 \mathrm{~kg} \mathrm{~N} / \mathrm{ha}$, sendo essa de $1.713 \mathrm{~kg} \mathrm{PV} / \mathrm{ha}$. O desempenho animal médio de 0,66 kg GPD não foi alterado pelas doses de nitrogênio, enquanto a taxa de lotação obtida na dose de $450 \mathrm{~kg} \mathrm{~N} / \mathrm{ha}$ foi de $10 \mathrm{UA} / \mathrm{ha}$.

Em Uberaba - MG, durante o período de novembro a março, Aguiar et al. (2002a) em pastagens de capim tanzânia e mombaça adubadas respectivamente com 533 e $523 \mathrm{~kg} \mathrm{~N} / \mathrm{ha}$ e com garrotes cruzados (nelore x piemontês, nelore $x$ simental, nelore $x$ limousin), obtiveram produtividades de 1.590 e $1.410 \mathrm{~kg}$ PV/ha. As taxas de lotação e desempenhos animais 
correspondentes foram de 7,2 UA/ha e 0,65 kg GPD e 7,0 UA/ha e 0,72 kg GPD, respectivamente para os capins tanzânia e mombaça.

Os crescentes níveis da adubação nitrogenada utilizados, acompanhados de produtividades também crescentes, dão indicativos da preocupação com a elevação da produtividade pecuária em regiões de terras valorizadas como nas que foram desenvolvidos esses trabalhos.

Outra técnica utilizada objetivando incrementos em produtividade é a irrigação de pastagens tropicais. Desde o final da década de 90, a irrigação de pastagens adubadas intensivamente cresce no Brasil Central, motivada pela expectativa de resultados produtivos elevados como os divulgados por revistas técnicas especializadas. Entretanto, a literatura é pobre em trabalhos que avaliem a produtividade de pastagens irrigadas, 0 que motiva 0 desenvolvimento de pesquisas abordando essa modalidade de exploração.

Dessa forma, o presente trabalho objetiva comparar os resultados de pastagens adubadas intensivamente com e sem o uso da irrigação, quanto à produtividade animal e seus componentes, desempenho animal e taxa de lotação.

\subsection{Material e métodos}

\subsubsection{Caracterização da área experimental}

Dois experimentos, um irrigado e outro sem irrigação, foram conduzidos durante o período de 24 de agosto de 2001 a 19 de agosto de 2002, na Fazenda Areão, pertencente à Escola Superior de agricultura "Luiz de Queiroz" (ESALQUSP), em Piracicaba - SP (576 m altitude, latitude 2241'30" sul, longitude 47³8'00" oeste) como parte integrante do Projeto Temático "Avaliação de um sistema de produção animal sob pastejo em capim tanzânia (Panicum maximum Jacq.) irrigado". 
As pastagens de capim tanzânia (Panicum maximum Jacq.) foram estabelecidas em março de 1999 num solo classificado como argissolo vermelho (EMBRAPA-CNPS, 1999). Informações precisas relativas æ̀े etapas e operações de estabelecimento da pastagem foram descritas em Penati (2002). Cada experimento consistia em 1,6 ha de pastagens, divididos em quatro parcelas em formato de fatias de pizza, subdivididas em três piquetes cada uma, com a finalidade de facilitar o manejo. As características químicas dos solos antes do início do experimento são apresentadas na tabela 1.

Tabela 1. Características químicas das áreas experimentais antes do início do experimento.

\begin{tabular}{|c|c|c|c|c|c|c|c|c|c|c|c|c|c|}
\hline \multirow[t]{2}{*}{ Exper. } & $\mathrm{MO}$ & $P$ & ${\mathrm{~S}-\mathrm{SO}_{4}}_{4}$ & $\mathrm{~K}$ & $\mathrm{Ca}$ & $\mathrm{Mg}$ & $\bar{T}$ & $\bar{V}$ & $B$ & $\mathrm{Cu}$ & $\mathrm{Fe}$ & $\mathrm{Mn}$ & $\mathrm{Zn}$ \\
\hline & \multicolumn{3}{|c|}{$\mathrm{mg} \mathrm{dm}^{3}$} & \multicolumn{4}{|c|}{ mmolc $\mathrm{dm}^{-3}$} & $\%$ & \multicolumn{5}{|c|}{$\mathrm{mg} \mathrm{dm}^{-3}$} \\
\hline Irrigado & 20,2 & 20 & 72,5 & 4,9 & 39 & 18 & 100 & 62 & 0,4 & 2,9 & 77,8 & 53,3 & 4,1 \\
\hline $\begin{array}{l}\text { Não } \\
\text { irriq. }\end{array}$ & 22,5 & 12 & 80,8 & 5,9 & 40 & 19 & 99 & 66 & 0,2 & 2 & 39,8 & 22,1 & 0,8 \\
\hline
\end{tabular}

Ambos os experimentos receberam calagem antes do início do período experimental, objetivando alcançar uma saturação de bases de $80 \%$. Também foi promovida adubação fosfatada objetivando alcançar $30 \mathrm{mg}$ de $\mathrm{P} / \mathrm{dm}^{3}$.

A área referente ao experimento irrigado era irrigada por aspersão via pivô central, sendo o manejo da irrigação efetuado por tensiometria. As irrigações eram realizadas quando os tensiômetros instalados a $20 \mathrm{~cm}$ de profundidade indicavam valores médios de tensão no solo entre - 0,03 e - 0,04 MPa conforme proposta de Lourenço et al. (2001).

\subsubsection{Manejo da pastagem}

Os experimentos foram manejados com 3 dias de ocupação e 33 dias de descanso, exceto no período compreendido entre 15 de janeiro a 30 de abril de 
2002, quando o período de descanso foi reduzido para 30 dias através do uso de dois lotes de pastejo (lote de ponta e de repasse) cada um com 3 dias de ocupação. Essa estratégia objetivou aumentar a freqüência de desfolha no período de maior desenvolvimento das hastes reprodutivas, permitindo aos animais o consumo desse componente morfológico antes do declínio acentuado do seu valor nutritivo.

A carga animal por piquete objetivava alcançar ao término do período de ocupação uma massa de forragem verde após o pastejo entre 2500 e 3000 kg MS/ha conforme proposta de Penati (2002). Antes dos animais entrarem em cada piquete eram feitas avaliações visuais da massa de forragem existente por avaliadores treinados via calibração por meio de métodos diretos de estimativa de massa de forragem. A média das avaliações visuais era utilizada, juntamente com a massa de forragem verde objetivada após o pastejo, a estimativa da massa de forragem consumida pelos animais (nos três dias de ocupação do piquete) e os resultados periodicamente obtidos de massa de forragem perdida por pastejo (expressos em função da forragem ofertada) e de porcentagem de forragem verde anterior ao pastejo (expressos em função da forragem ofertada), para o cálculo do número de animais necessário em cada piquete usando a Eq. (4). Durante o período em que houve dois lotes, o número de animais do primeiro lote era calculado de modo a se obter nesse aproximadamente $70 \%$ da carga animal total dos dois lotes.

$$
N A P=\frac{[(M A P-M A P * \% P F) * \% F V O-M F V P P] * T P}{M C A}
$$

Onde:

- NAP $\rightarrow$ número de animais por piquete;

- MAP $\rightarrow$ massa de forragem anterior ao pastejo ( $\mathrm{kg} \mathrm{MS} / \mathrm{ha}$ );

- \%PF $\rightarrow$ porcentagem de perdas de forragem expressa em função da forragem ofertada; 
- \%FVO $\rightarrow$ porcentagem de forragem verde expressa em função da forragem ofertada;

- MFVPP $\rightarrow$ massa de forragem verde objetivada após o pastejo (kg MSV/ha);

- $\quad$ TP $\rightarrow$ tamanho do piquete a ser pastejado (ha);

- MCA $\rightarrow$ estimativa da massa de forragem consumida pelo animal calculada com base no peso médio dos animais e assumindo um consumo diário de $2,25 \%$ do PV de massa de forragem seca (kg MS).

O experimento irrigado recebeu $500 \mathrm{~kg} \mathrm{~N}, 58 \mathrm{~kg} \mathrm{P} \mathrm{O}_{5}, 19 \mathrm{~kg} \mathrm{~S} \mathrm{e} \mathrm{1,9} \mathrm{kg} \mathrm{B}$ por hectare, parcelados ao longo do período de "águas" em sete vezes,

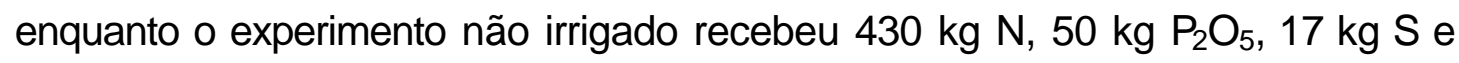
$1,7 \mathrm{~kg} \mathrm{~B}$, parcelados em seis vezes também no período de "águas". As adubações eram efetuadas no dia seguinte àsaída dos animais dos piquetes.

\subsubsection{Caracterização e manejo dos animais}

Foram utilizados novilhos nelore castrados na desmama e previamente adaptados ao manejo antes do início do experimento, quando se encontravam com 8 meses de idade. Os animais foram divididos em duas classes, "testers" (no número de três por experimento) e "de ajuste de carga", sendo que os primeiros foram os únicos que permaneceram em pastejo nas áreas experimentais ao longo de todo o período. O peso médio dos animais "testers" no início do período experimental era de respectivamente 207 kg e 213 kg para o experimento irrigado e em sequeiro.

Durante o período em que foi empregado pastejo com dois lotes, foram escolhidos mais três "testers" de repasse para cada experimento, que também permaneceram em pastejo durante todo esse período.

Os animais eram vermifugados a cada 36 dias e recebiam sal mineral à vontade em cochos móveis localizados nos piquetes. 


\subsubsection{Métodos de avaliação}

\section{Produtividade animal}

O desempenho animal foi avaliado através da pesagem dos animais "testers" a cada 36 dias após jejum de 14 horas. O desempenho animal quando se utilizou lote de repasse foi calculado ponderando-se os desempenhos de cada lote pelas suas respectivas cargas animais.

A taxa de lotação foi calculada com base na carga animal (kg PV) existente diariamente em cada piquete ao longo do período experimental, sendo essa obtida através da somatória do peso dos animais presentes no piquete diariamente. No cálculo da carga animal eram computados tanto os pesos dos animais "testers" quando dos animais "de ajuste de carga", sendo que esses últimos eram pesados periodicamente juntamente com os animais "testers". A carga animal era então corrigida para unidade animal (1 UA $\rightarrow 450 \mathrm{~kg} \mathrm{PV}$ ) e dividida pela área total do experimento para a obtenção da taxa de lotação em cada piquete.

A produtividade animal ( $\mathrm{kg} \mathrm{PV} / \mathrm{ha}$ ) foi calculada através do produto entre o desempenho animal e a taxa de lotação, ajustada em função do peso médio dos animais "testers" de cada experimento.

\section{Características estruturais}

Foram efetuadas avaliações de massa de forragem pré e pós-pastejo a cada nove dias, utilizando cinco sub-amostras quadradas de um metro de lado por piquete conforme proposta de Penati et al. (2001), sendo a forragem cortada a dez centímetros da superfície do solo. As sub-amostras eram dispostas sistematicamente em linhas transectas que eram alteradas de local a cada ciclo de pastejo, de maneira a evitar que um local fosse amostrado mais de uma vez. Tal procedimento foi necessário em decorrência do reduzido tamanho dos piquetes $(0,13 \mathrm{ha})$ e do elevado número de amostras. Em cada sub-amostra era efetuada a medição da altura indeformada da pastagem com o 
auxílio de uma trena, em quatro pontos dispostos em cada um dos quadrantes do quadrado amostral. Nessa determinação, a altura da pastagem era considerada como sendo a distância entre a superfície do solo e a curvatura das folhas. A forragem coletada era pesada e sub-amostrada para a determinação dos componentes morfológicos: lâminas foliares, haste (bainha e haste) e material morto. As sub-amostras eram então levadas à estufa com circulação de ar forçada a $65{ }^{\circ} \mathrm{C}$ de temperatura, para a determinação do teor de matéria seca.

A densidade "bulk" da pastagem foi obtida pela razão entre a massa de forragem anterior ao pastejo obtida em cada sub-amostra corrigida para a área de um hectare e a média das alturas obtidas na mesma.

A oferta de forragem verde foi obtida pela razão entre a média de forragem verde antes e após o pastejo e a carga animal média de cada parcela. Cálculo semelhante foi efetuado para a determinação da oferta de lâminas foliares.

\subsubsection{Forma de análise dos resultados}

Os resultados obtidos foram analisados utilizando o modelo de parcelas subdivididas no tempo, utilizando o procedimento "mixed" do pacote estatístico SAS (SAS, 1995). As médias foram comparadas pelo Teste de Tukey com nível de significância de $5 \%$.

\subsection{Resultados e discussão}

\subsubsection{Desempenho animal}

Os resultados de todas as variáveis analisadas foram agrupados em períodos compreendendo dois ciclos de pastejo sucessivos, dessa forma totalizando cinco períodos de pastejo. Os resultados de desempenho animal obtidos ao longo do período experimental são apresentados na tabela 2. A interação entre experimento e período foi significativa $(P=0,0004)$, de forma 
Tabela 3. Massa de forragem verde pós-pastejo $\left(\mathrm{kg} \mathrm{MS}^{*} \mathrm{ha}^{-1}\right)$ nos períodos experimentais.

\begin{tabular}{cccc}
\hline \multirow{2}{*}{ Período } & \multicolumn{2}{c}{ Experimento } & \multirow{2}{*}{ Média } \\
\cline { 2 - 3 } & Irrigado & Não irrigado & \\
\hline $\mathbf{1}$ & 3.814 & 3.087 & $\mathbf{3 . 4 5 1} \mathbf{a}$ \\
$\mathbf{2}$ & 2.187 & 2.410 & $\mathbf{2 . 2 9 9} \mathbf{b c}$ \\
$\mathbf{3}$ & 3.325 & 3.703 & $\mathbf{3 . 5 1 4} \mathbf{a}$ \\
$\mathbf{4}$ & 2.896 & 2.777 & $\mathbf{2 . 8 3 6} \mathbf{~ b}$ \\
$\mathbf{5}$ & 2.087 & 2.220 & $\mathbf{2 . 1 5 4} \mathbf{~ C}$ \\
Média & $\mathbf{2 . 8 6 2}$ & $\mathbf{2 . 8 3 9}$ & $\mathbf{2 . 8 5 1}$ \\
\hline
\end{tabular}

Tabela 4. Densidade "bulk" das pastagens $\left(\mathrm{kg} \mathrm{MS}^{*} \mathrm{Cm}^{-1 *} \mathrm{ha}^{-1}\right)$ nos períodos experimentais.

\begin{tabular}{cccc}
\hline \multirow{2}{*}{ Período } & \multicolumn{2}{c}{ Experimento } & \multirow{2}{*}{ Média } \\
\cline { 2 - 3 } & Irrigado & Não irrigado & \\
\hline $\mathbf{1}$ & 128 & 153 & $\mathbf{1 4 1} \mathbf{a}$ \\
$\mathbf{3}$ & 115 & 156 & $\mathbf{1 3 5} \mathbf{a}$ \\
$\mathbf{4}$ & 106 & 107 & $\mathbf{1 0 7} \mathbf{~ b}$ \\
$\mathbf{5}$ & 132 & 162 & $\mathbf{1 4 7} \mathbf{a}$ \\
Média & 164 & 145 & $\mathbf{1 5 2} \mathbf{a}$ \\
\hline médias seguidas da mesma letra na coluna não diferem por tukey a 5\% de probabilidade.
\end{tabular}


Tabela 5. Relação folha/haste média antes e após o pastejo nos períodos experimentais.

\begin{tabular}{cccc}
\hline \multirow{2}{*}{ Período } & \multicolumn{2}{c}{ Experimento } & \multirow{2}{*}{ Média } \\
\cline { 2 - 3 } & Irrigado & Não irrigado & \\
\hline $\mathbf{1}$ & 0,71 & 0,65 & $\mathbf{0 , 6 8 \mathbf { a }}$ \\
$\mathbf{2}$ & 0,73 & 0,71 & $\mathbf{0 , 7 2} \mathbf{a}$ \\
$\mathbf{3}$ & 0,69 & 0,66 & $\mathbf{0 , 6 7} \mathbf{a}$ \\
$\mathbf{4}$ & 0,40 & 0,35 & $\mathbf{0 , 3 7} \mathbf{~}$ \\
$\mathbf{5}$ & 0,57 & 0,45 & $\mathbf{0 , 5 1} \mathbf{~ b}$ \\
Média & $\mathbf{0 , 6 2}$ & $\mathbf{0 , 5 6}$ & $\mathbf{0 , 5 9}$ \\
\hline
\end{tabular}

Tabela 6. Relação folha/haste após o pastejo nos períodos experimentais.

\begin{tabular}{|c|c|c|c|}
\hline \multirow{2}{*}{ Período } & \multicolumn{2}{|c|}{ Experimento } & \multirow{2}{*}{ Média } \\
\hline & Irrigado & Não irrigado & \\
\hline 1 & 0,35 & 0,42 & $0,38 a^{1}$ \\
\hline 2 & 0,17 & 0,15 & $0,16 \mathrm{~b}$ \\
\hline 3 & 0,39 & 0,30 & $0,34 a$ \\
\hline 4 & 0,11 & 0,10 & $0,11 \mathrm{~b}$ \\
\hline 5 & 0,43 & 0,31 & 0,37 a \\
\hline Média & 0,29 & 0,26 & 0,27 \\
\hline
\end{tabular}

Durante os períodos 1 e 5 , foram verificados déficits hídricos que podem ter afetado o valor nutritivo da forragem consumida, justificando o maior desempenho do experimento não irrigado. Wilson (1983) verificou que plantas de Panicum maximum cv. green panic submetidas a sucessivos ciclos de déficits hídricos de curta duração (12 a 14 dias) ou a um déficit hídrico de longa duração (42 dias), apresentavam maior digestibilidade do que plantas mantidas sem déficit. A análise do balanço hídrico do experimento sem irrigação, 
elaborado segundo Thornthwaite \& Mather (1955) (figura 1), permite concluir que a primeira situação foi muito semelhante à ocorrida no período 1, enquanto a segunda se aproxima da ocorrida no período 5 , fato que sugere a existência de diferenças de valor nutritivo entre os experimentos. A maior digestibilidade das plantas submetidas ao estresse hídrico está associada ao menor acúmulo de parede celular com o avanço da maturidade (Wilson \& $\mathrm{Ng}$, 1975), maior acúmulo de solutos no conteúdo celular (Wilson et al., 1980) e aumento da relação folha/haste (Snaydon, 1972; Halim et al., 1989).

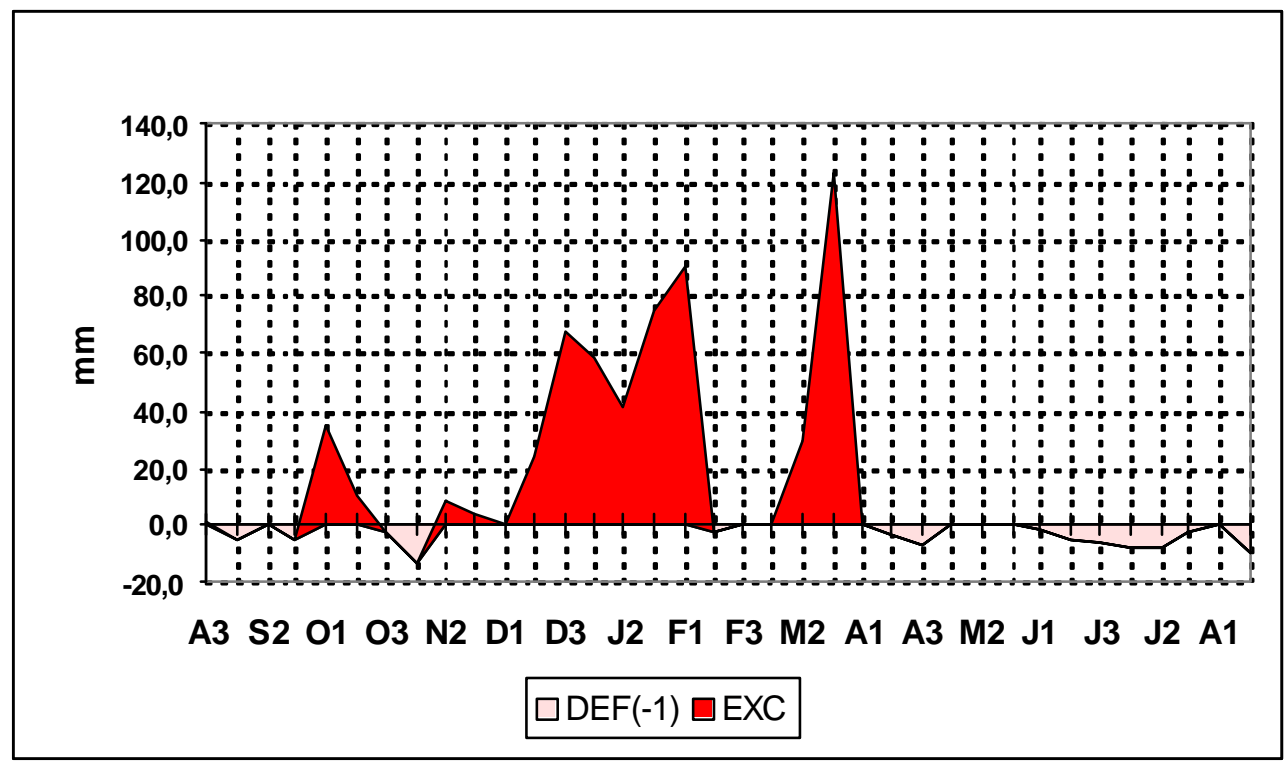

Figura 1 - Balanço hídrico decendial para o experimento sem irrigação.

Contudo, seria necessário um diferencial de valor nutritivo muito grande entre os experimentos para justificar o desempenho animal $0,385 \mathrm{~kg}$ superior para o experimento em sequeiro no período 1. Com base nas equações propostas pelo NRC (1996) foram calculados os valores adicionais de nutrientes digestíveis totais (NDT) da forragem e de consumo necessários para justificar o desempenho animal superior do experimento sem irrigação nos períodos 1 e 5 (Tabela 7). Os resultados mostram que seria necessário um NDT 10,5 unidades 
superior na pastagem sem irrigação para que o diferencial de desempenho no período 1 fosse devido apenas ao valor nutritivo, o que é pouco provável que tenha ocorrido. Os resultados de Wilson (1983) mostram magnitude de diferença menor entre o valor nutritivo de plantas com e sem estresse hídrico, com digestibilidade uma unidade maior para fração folha e 6,5 unidades maior para a fração haste, em plantas submetidas a esse estresse. Embora não fossem detectadas diferenças entre os experimentos nas características estruturais das pastagens, o que poderia dar um indicativo de um consumo também diferente, a explicação do maior desempenho animal do experimento não irrigado no período 1 passa necessariamente por um consumo de forragem maior quando comparado ao experimento irrigado. 
Tabela 7. Adicionais de NDT e de consumo da forragem no experimento não irrigado em relação ao irrigado, necessários para justificar a diferença de desempenho animal entre os experimentos nos períodos 1 e 5 segundo o NRC (1996).

\begin{tabular}{|c|c|c|}
\hline \multirow[t]{2}{*}{ Variação no NDT (unidades) } & Período ${ }^{1}$ & Período 5 \\
\hline & \multicolumn{2}{|c|}{ Adicional de consumo (\%) } \\
\hline 0 & 42 & 13 \\
\hline 1 & 35 & 9 \\
\hline 2 & 31 & 5 \\
\hline 3 & 26 & 2 \\
\hline 3,5 & 24 & 0 \\
\hline 4 & 21 & - \\
\hline 5 & 17 & - \\
\hline 6 & 14 & - \\
\hline 7 & 10 & - \\
\hline 8 & 7 & - \\
\hline 9 & 4 & - \\
\hline 10 & 1 & - \\
\hline 10,5 & 0 & - \\
\hline
\end{tabular}

A variação dos resultados de desempenho animal entre os períodos de pastejo esteve associada a alterações estruturais das pastagens entre os períodos avaliados, como atestam os resultados apresentados nas tabelas 3,4 , 5 e 6.

A proposta de manutenção de uma massa de forragem verde após 0 pastejo entre 2500 e $3000 \mathrm{~kg} \mathrm{MSV/ha} \mathrm{não} \mathrm{foi} \mathrm{atingida} \mathrm{em} \mathrm{alguns} \mathrm{períodos,}$ resultando em alterações qualitativas na forragem ofertada aos animais (tabela 3). As massas de forragem pós-pastejo superiores ao valor objetivado no 
período 1 foram conseqüência de um período de acerto da condição estrutural da planta forrageira ocorrido desde fevereiro de 2001. Anteriormente a esse período, as pastagens vinham sendo manejadas com massas de forragem póspastejo diferentes, de modo que foi necessário algum tempo até a uniformização dessas através do pastejo. A elevação da massa de forragem verde pós-pastejo no período 3 foi decorrente da elongação das hastes reprodutivas da planta forrageira. No período 5 , embora não tenha sido atingido o valor preconizado para a massa de forragem pós-pastejo, a composição morfológica dessa forragem, com elevada participação de folhas, acabou possibilitando elevados ganhos de peso (tabela 2). Em ambos experimentos, 0 valor médio de massa de resíduo pós-pastejo esteve muito próximo dos 2.833 $\mathrm{kg} \mathrm{MSV/ha} \mathrm{apontados} \mathrm{por} \mathrm{Balsalobre} \mathrm{(2002)} \mathrm{como} \mathrm{sendo} \mathrm{o} \mathrm{valor} \mathrm{que} \mathrm{possibilita}$ o máximo consumo para pastagens de capim tanzânia irrigadas durante 0 verão.

A análise conjunta das tabelas 2 e 3 permite constatar que os períodos de menor desempenho animal ocorreram sempre após períodos de maior massa de forragem verde pós-pastejo. Maiores massas de forragem póspastejo favoreceram a deterioração estrutural da planta forrageira por meio da elongação das hastes, o que no período subseqüente acabou por ocasionar redução do consumo do animal e conseqüentemente queda no desempenho.

Stobbs (1973a, b) verificou a importância da densidade "bulk" da pastagem na definição do tamanho de bocados que por sua vez apresenta elevada correlação com o desempenho de animais em pastejo (Chacon et al., 1978). A relação folha/haste é também apontada como característica estrutural de elevada influência sobre o desempenho animal, devido aos seus efeitos sobre o consumo (Chacon \& Stobbs, 1976; Chacon et al., 1978). Em ambos experimentos, as diferenças de desempenho entre períodos estiveram associadas a variações entre períodos nessas características estruturais.

Hillesheim (1987), Balsalobre (1996) e Barbosa et al. (2001) relataram a respeito da relação existente entre a oferta de forragem e o consumo e 
desempenho de animais em pastejo. As ofertas médias de forragem verde e de lâminas foliares não se mostraram diferentes entre os experimentos (tabelas $8 \mathrm{e}$ 9), mais uma vez demonstrando que o manejo imposto em ambos foi muito semelhante, não justificando as diferenças de ganho de peso verificadas nos períodos 1 e 5.

Tabela 8. Oferta média de forragem verde antes e após o pastejo (kg MS/100 $\mathrm{kg}$ PV) nos períodos experimentais.

\begin{tabular}{cccc}
\hline \multirow{2}{*}{ Período } & \multicolumn{2}{c}{ Experimento } & \multirow{2}{*}{ Média } \\
\cline { 2 - 3 } & Trrigado & Não írrigado & \\
\hline $\mathbf{1}$ & 18,2 & 19,3 & $\mathbf{1 8 , 7} \mathbf{b}$ \\
$\mathbf{3}$ & 10,7 & 8,3 & $\mathbf{9 , 5} \mathbf{c}$ \\
$\mathbf{4}$ & 14,0 & 14,6 & $\mathbf{1 4 , 3} \mathbf{b c}$ \\
$\mathbf{5}$ & 14,9 & 15,1 & $\mathbf{1 5 , 0} \mathbf{b c}$ \\
Média & 30,2 & 25,7 & $\mathbf{2 7 , 9} \mathbf{a}$ \\
& $\mathbf{1 7 , 6}$ & $\mathbf{1 6 , 6}$ & $\mathbf{1 7 , 1}$ \\
\hline
\end{tabular}

Tabela 9. Oferta média de lâminas foliares antes e após o pastejo (kg MS/100 $\mathrm{kg} P \mathrm{~V})$ nos períodos experimentais.

\begin{tabular}{cccc}
\hline \multirow{2}{*}{ Período } & \multicolumn{2}{c}{ Experimento } & \multirow{2}{*}{ Média } \\
\cline { 2 - 3 } & Irrigado & Não irrigado & \\
\hline 1 & 7,0 & 7,6 & $\mathbf{7 , 3} \mathbf{~ b}$ \\
3 & 4,0 & 3,6 & $3,8 \mathrm{c}$ \\
4 & 5,8 & 6,0 & $5,9 \mathrm{~b}$ \\
5 & 3,8 & 3,6 & $3,7 \mathbf{~ C}$ \\
Média & 11,8 & 8,4 & $\mathbf{1 0 , 1} \mathbf{a}$ \\
& 6,5 & 5,9 & $\mathbf{6 , 2}$ \\
\hline
\end{tabular}


A taxa de ganho de peso do experimento sem irrigação foi inferior aos resultados obtidos por Corrêa (1999), Tosi (1999) e Aguiar (2001b) em pastagens de capim tanzânia, respectivamente 0,68, 0,65 e 0,68 kg GPD. Tal fato pode estar associado tanto àqualidade da planta forrageira, decorrente do manejo imposto sobre ela, quanto æ̀ diferenças relativas æ̀s raças e categorias animais utilizadas.

Corrêa (1999) e Tosi (1999) utilizaram respectivamente novilhas e garrotes inteiros da raça canchim, enquanto Aguiar (2001b) trabalhou com animais zebuínos (guzerá e tabapuã) e cruzados nelore $x$ limosin e nelore $x$ piemontês. Diversos trabalhos têm abordado as diferenças quanto ao potencial genético de animais zebuínos e seus cruzamentos industriais, sendo que os últimos têm apresentado ganho de peso cerca de $15 \%$ superior, quando submetidos a dietas de valor nutritivo mediano a alto (Oliveira et al., 1991; Euclides Filho, 1997; Euclides Filho et al., 2001). O desempenho animal superior para machos inteiros em relação a castrados também seria outra justificativa para o menor ganho de peso no experimento não irrigado quando comparado aos resultados de Tosi (1999).

O parâmetro de manejo do pastejo utilizado em cada trabalho também justificaria as diferenças de desempenho. Enquanto no presente experimento as pastagens foram manejadas objetivando atingir uma massa de forragem póspastejo entre 2500 e 3000 kg MSV/ha, nos trabalhos de Corrêa (1999) e Tosi (1999) objetivourse uma altura pós-pastejo entre 35 e $40 \mathrm{~cm}$ e em Aguiar et al. (2001b) uma disponibilidade de forragem de $5 \%$ do peso vivo.

No experimento com irrigação, o desempenho animal médio de 0,492 kg GPD se mostrou inferior aos 0,541 kg GPD obtidos por Penati (2002) em pastagens de capim tanzânia, irrigadas e manejadas com intensidades e freqüências de desfolha semelhantes e com a mesma raça e categoria animal do presente trabalho.

Embora inferiores aos resultados de literatura citados, os ganhos de peso médios obtidos em cada experimento possibilitariam o abate dos animais do 
eliminação dos déficits hídricos ocorridos entre os meses de agosto e novembro, refletindo sobre a taxa de lotação do experimento irrigado nesse período. Esse seria um dos benefícios atribuídos à irrigação de pastagens, a antecipação do início da estação de pastejo, quando as condições de temperatura não são limitantes para a planta e ainda não se tem o início da estação chuvosa.

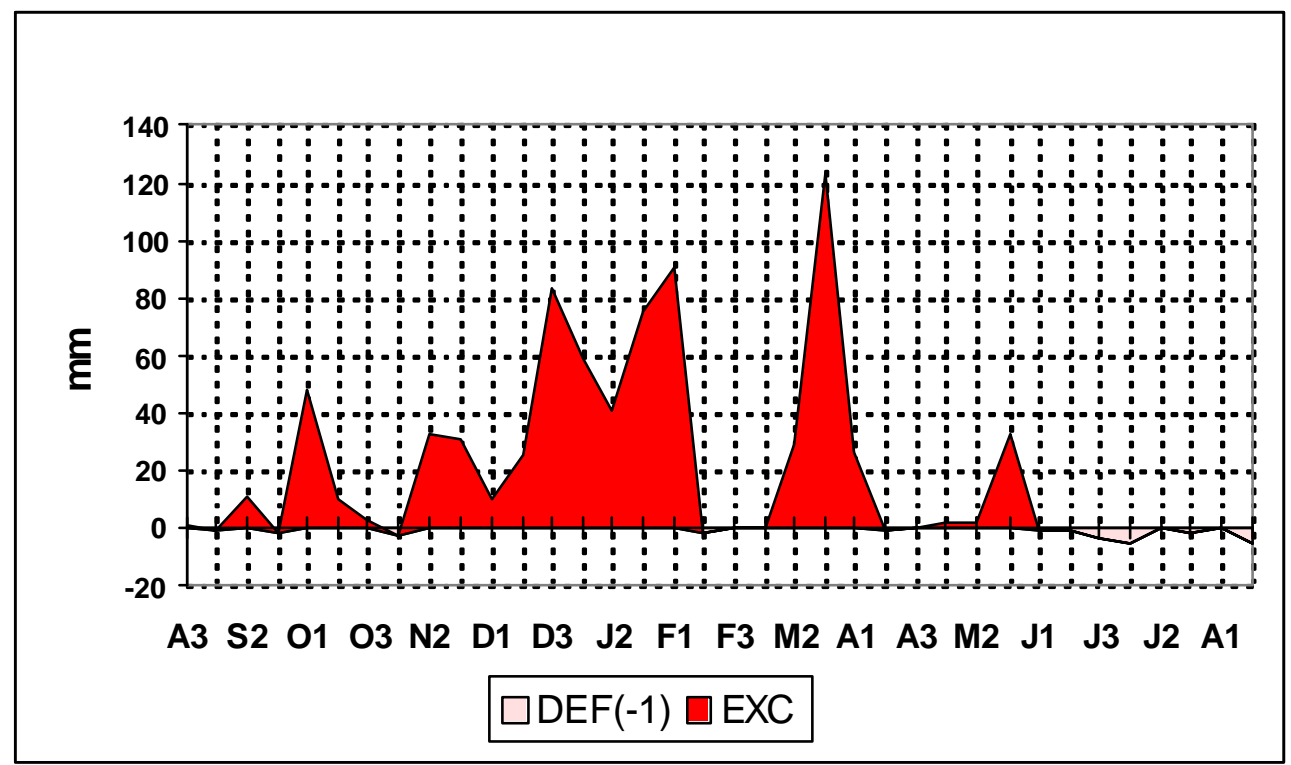

Figura 2 - Balanço hídrico decendial para o experimento com irrigação.

A inexistência de resposta da taxa de lotação à irrigação nos demais períodos pode ser justificada por um conjunto de fatores. Diversos autores já relataram a respeito da pequena resposta a irrigação de forrageiras tropicais em regiões com temperatura e fotoperíodo limitantes ao desenvolvimento da planta forrageira durante o período seco do ano, como é o caso da região de Piracicaba (Carvalho et al., 1975; Ghelfi Filho, 1978; Alvim et al., 1986; Alvim et al., 1993; Marcelino et al., 2001). Nessas regiões o maior benefício da irrigação se daria na eliminação dos déficits hídricos durante o período das "águas", quando as condições de temperatura e fotoperíodo não são limitantes. No ano 
experimental, entretanto, os déficits hídricos ocorridos durante o período de "águas" foram raros e de pequena intensidade, como se pode observar no balanço hídrico apresentado na figura 1.

A variabilidade das características físicas do solo nas áreas experimentais também contribuiu para a inexistência de resposta à irrigação. Gonçalves (1997) verificou variação de 141\% no armazenamento de água na faixa de tensão monitorada por tensiômetros na mesma área experimental, o que atesta a grande variação nas características físicas do solo da área na qual foram desenvolvidos os experimentos. O experimento irrigado foi locado numa área de pior drenagem quando comparada àárea do experimento não irrigado, fato que fez com que durante os meses de janeiro e fevereiro, período em que se verificou elevado excedente hídrico (figura 2), ocorresse encharcamento de determinados pontos. Durante esse ciclo de pastejo, a taxa de lotação verificada na área irrigada foi de 6,1 UA/ha enquanto na área não irrigada foram obtidas 9,3 UA/ha (dados não apresentados). O resultado desse ciclo de pastejo acabou por minimizar a diferença de taxa de lotação média anual entre os experimentos.

Trabalhos recentes com irrigação de pastagens sugerem que a planta forrageira possui uma capacidade de compensar períodos de baixo crescimento decorrentes de déficits hídricos, através de maior crescimento após o restabelecimento das condições ideais de disponibilidade de água. No presente trabalho, esse fato parece também ter sido verificado, dada a semelhança entre os valores de taxa de lotação obtidos nos experimentos, mesmo durante o período seco do ano. A ausência de resposta àirrigação também foi verificada em outros trabalhos como os de Marcelino et al. (2001) e Pinheiro (2002).

A análise dos dados de precipitação e temperatura do ano experimental (figuras 3 e 4) demonstra que o período de seca iniciado em abril de 2002 foi caracterizado por temperaturas médias superiores æ̀ temperaturas médias normais, além de precipitações atípicas para a época. Esse fato contribuiu para 
as elevadas taxas de lotação obtidas em ambos experimentos durante esse período.

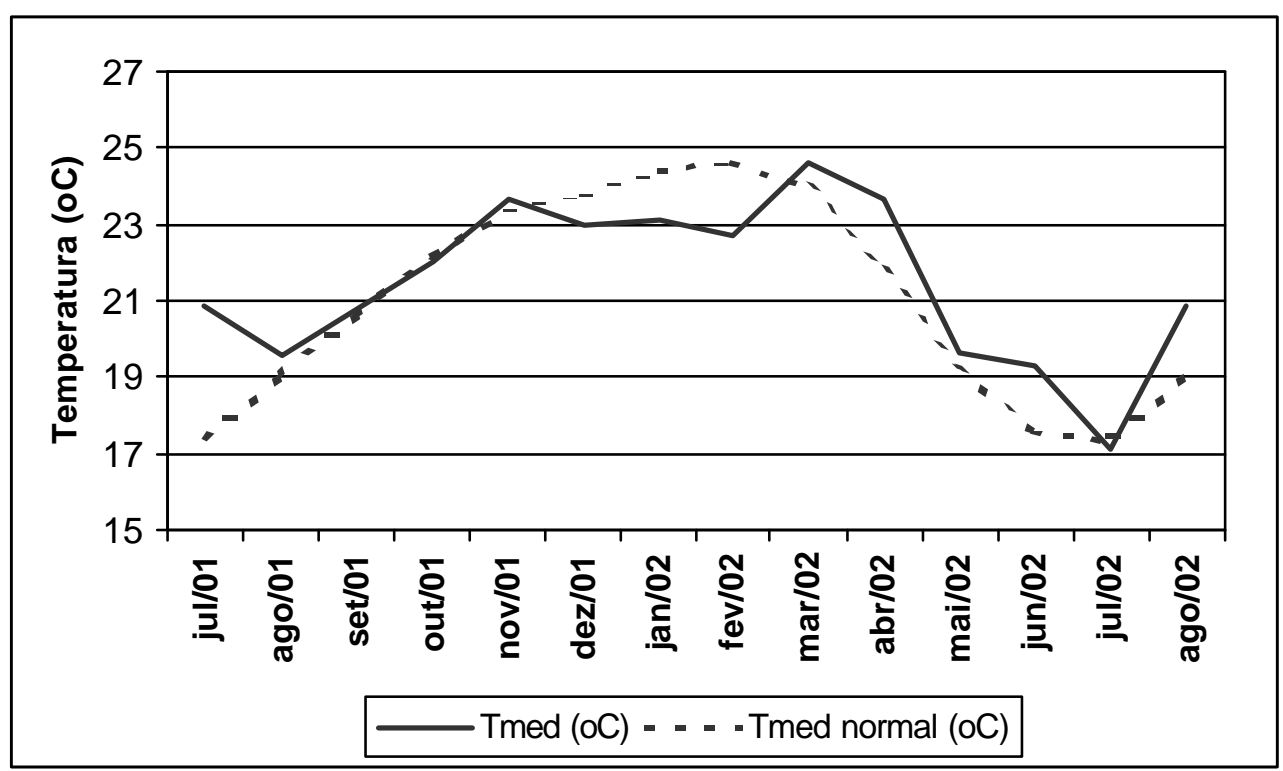

Figura 3 - Temperaturas médias mensais no ano experimental (Tmed) e temperaturas médias mensais normais para Piracicaba (Tmed normal).

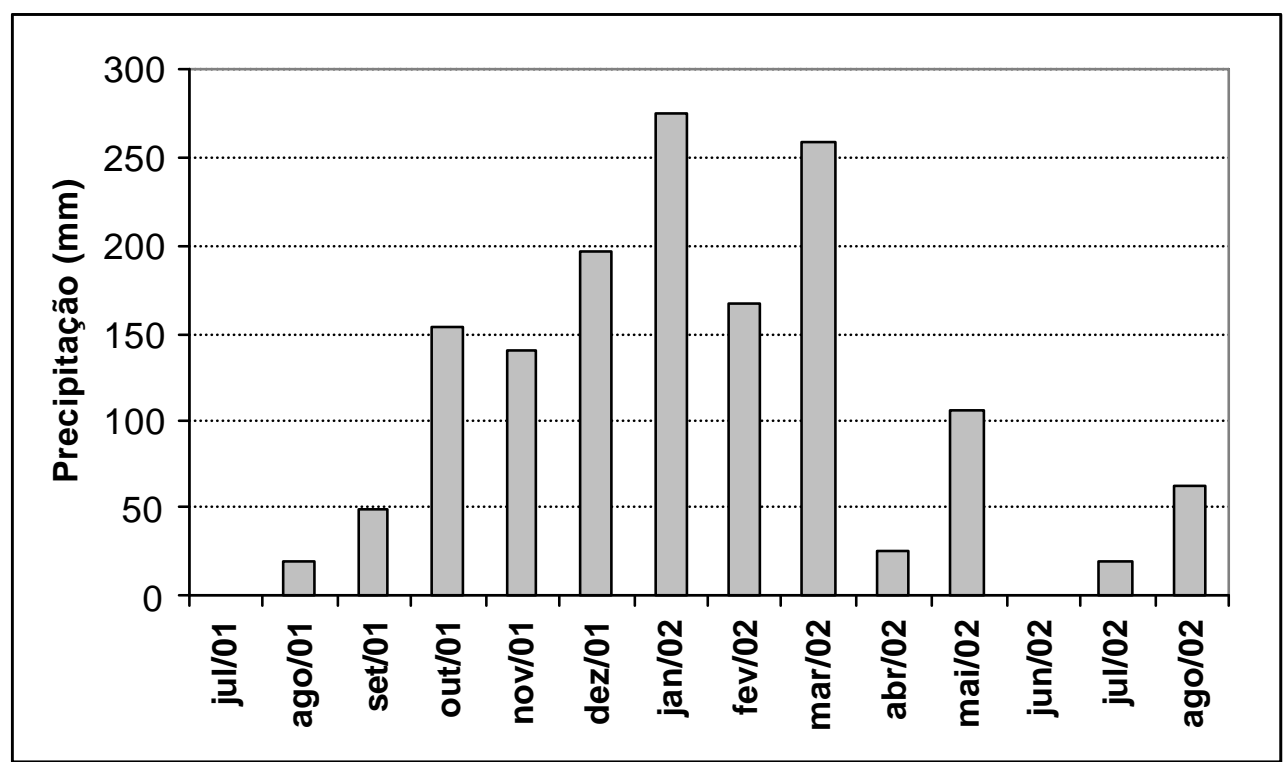

Figura 4 - Precipitações mensais no ano experimental. 
A taxa de lotação média anual obtida no experimento sem irrigação $(5,6$ UA/ha) foi superior à obtidas por Tosi (1999) e Aguiar et al. (2001b) em pastagens de capim tanzânia, respectivamente 4,8 UA/ha e 4,4 UA/ha. A maior taxa de lotação pode ser justificada em função da adubação nitrogenada utilizada, que em Tosi (1999) foi de $320 \mathrm{~kg} \mathrm{~N} / \mathrm{ha}^{*}$ ano e em Aguiar (2001b) 340 $\mathrm{kg} \mathrm{N} / \mathrm{ha} a^{*}$ ano, enquanto no presente experimento utilizou-se $430 \mathrm{~kg} \mathrm{~N} / \mathrm{ha}^{*}$ ano. Outro fato que colaborou para o resultado alcançado foi a regularidade da distribuição das precipitações.

$\mathrm{Na}$ comparação dos resultados parciais dos períodos de "águas" e "seca", os resultados obtidos, também se mostraram superiores à maior parte dos trabalhos relatados na literatura. Enquanto Tosi (1999), obteve 6,6 UA/ha no período de dezembro a abril e 2,7 UA/ha no período de maio a novembro, no experimento não irrigado nesse mesmo período, a taxa de lotação obtida foi de 8,3 UA/ha e 4,1 UA/ha, respectivamente. Aguiar et al. (2001b) obtiveram taxas de lotação de 7,9 e 6,5 UA/ha durante o período de novembro a abril e 2,9 e 2,8 UA/ha no período de maio a outubro, respectivamente para os capins mombaça e tanzânia, enquanto nesses mesmos períodos foram obtidas taxas de lotação de 8,8 UA/ha e 2,7 UA/ha no experimento sem irrigação. Num novo ano experimental, Aguiar et al. (2002a) obtiveram para o período de novembro a abril com $530 \mathrm{~kg} \mathrm{~N} / \mathrm{ha}, 7,2 \mathrm{UA} / \mathrm{ha}$ em pastagem de capim tanzânia e 7,0 UA/ha em pastagem de mombaça. Contudo, Lugão (2001) com adubação de $450 \mathrm{~kg}$ N/ha obteve com o acesso BRA-006998 de Panicum maximum Jacq., taxa de lotação de $10 \mathrm{UA} /$ ha durante o período de outubro a abril, sendo essa superior æ̀े $8,3 \cup A / h a$ obtidas no presente trabalho para esse período.

No experimento com irrigação a taxa de lotação de 5,9 UA/ha foi inferior ao resultado obtido por Penati (2002) em pastagens de capim tanzânia irrigadas (6,5 UA/ha), contudo nesse trabalho a adubação utilizada foi de $960 \mathrm{~kg} \mathrm{~N} / \mathrm{ha} \mathrm{e} \mathrm{a}$ duração do período experimental foi de 14 meses, compreendendo dois períodos de condição climática favorável ao desenvolvimento da planta forrageira. 


\subsubsection{Produtividade animal}

Os resultados de produtividade animal obtidos em cada um dos experimentos são apresentados na tabela 11.

Tabela 11. Produtividade animal (kg PV/ha) obtida nos períodos experimentais.

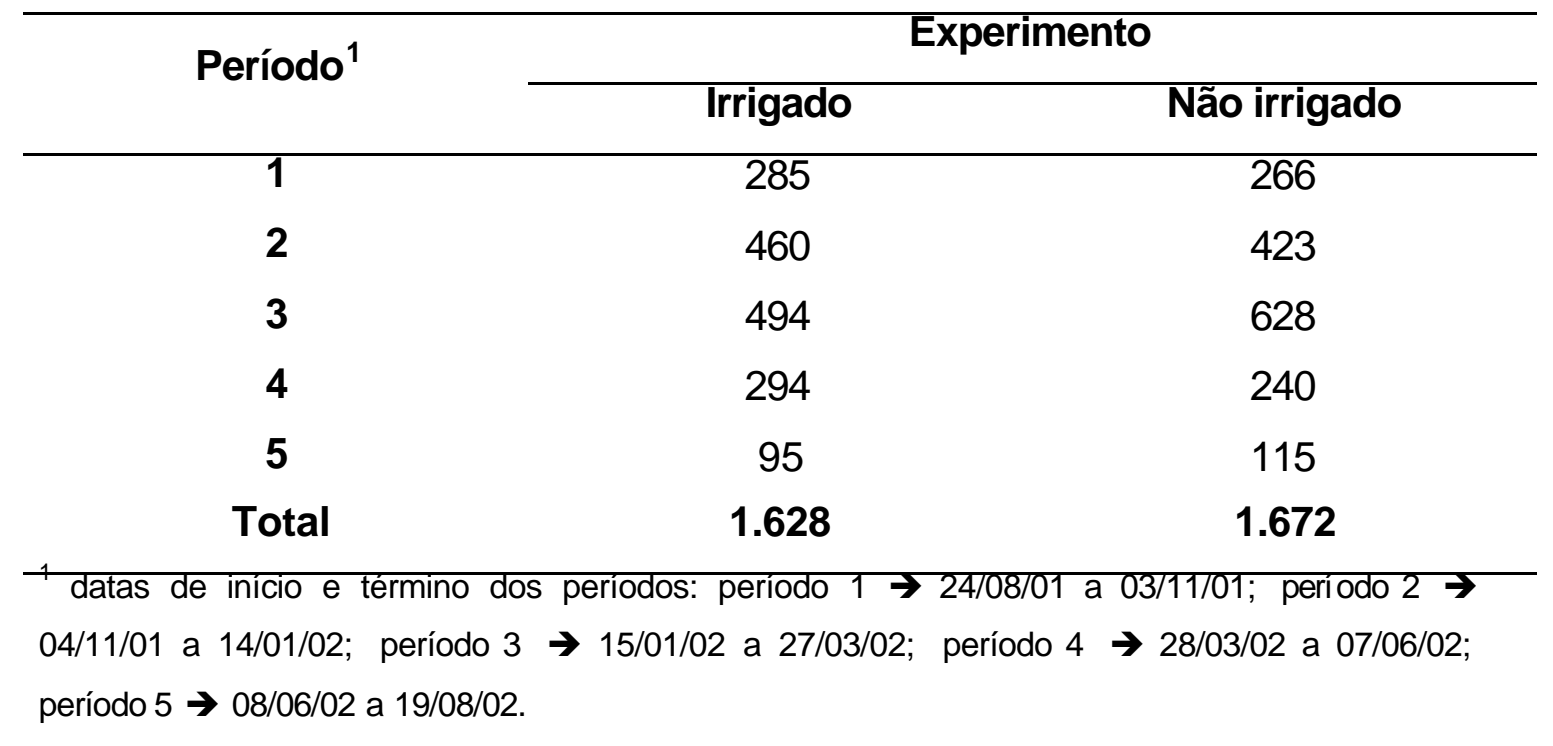

A diferença verificada entre a produtividade dos experimentos deveurse principalmente ao maior desempenho animal do experimento sem irrigação em alguns períodos (tabela 2). Apenas no período 1 a taxa de lotação do experimento irrigado foi superior e seu efeito sobre a produtividade do período foi praticamente anulado pelo maior desempenho obtido no experimento sem irrigação.

A produtividade obtida no experimento em sequeiro foi superior às obtidas por Tosi (1999) e Aguiar et al. (2001b) em pastagens de capim tanzânia, respectivamente 1.370 e 1.178 kg PV/ha*ano, e também aos resultados obtidos por Aguiar et al. (2001b) em pastagem de capim mombaça, $1.289 \mathrm{~kg} \mathrm{PV} / \mathrm{ha}{ }^{*}$ ano. Ressalta-se aqui a maior adubação nitrogenada utilizada no presente trabalho (430 $\mathrm{kg} \mathrm{N} / \mathrm{ha})$ o que parcialmente justifica as maiores produtividades obtidas. 
Contudo, a produtividade do experimento não irrigado se mostrou inferior aos resultados de trabalhos nos quais foram utilizados níveis maiores de adubação nitrogenada. Aguiar et al. (2002a) em pastagens de capim tanzânia e mombaça adubadas respectivamente com 533 e $523 \mathrm{~kg} \mathrm{~N} / \mathrm{ha}$, obteve durante o período de novembro a março produtividades de 1.590 e $1.410 \mathrm{~kg} \mathrm{PV/ha,}$ enquanto nesse mesmo período no experimento não irrigado foram obtidos $1.051 \mathrm{~kg} \mathrm{PV/ha.} \mathrm{No} \mathrm{período} \mathrm{de} \mathrm{outubro} \mathrm{a} \mathrm{abril,} \mathrm{Lugão} \mathrm{(2001)} \mathrm{com} 450 \mathrm{~kg} \mathrm{~N} / \mathrm{ha}$ obteve $1.713 \mathrm{~kg}$ PV/ha com o acesso de Panicum maximum Jacq. (BRA006998), enquanto no presente trabalho foram obtidos $1.411 \mathrm{~kg} \mathrm{PV} / \mathrm{ha}$.

A produtividade anual obtida no experimento com irrigação, $1.628 \mathrm{~kg}$ $\mathrm{PV} / \mathrm{ha}$, foi superior aos $1.518 \mathrm{~kg} \mathrm{PV/ha} \mathrm{obtidos} \mathrm{por} \mathrm{Penati} \mathrm{(2002),} \mathrm{em} \mathrm{quatorze}$ meses de período experimental com pastagens de capim tanzânia irrigadas. Entretanto, durante o período de julho a outubro, a produtividade obtida (343 kg $\mathrm{PV} / \mathrm{ha}$ ) foi inferior ao resultado de $576 \mathrm{~kg} \mathrm{PV/ha} \mathrm{alcançado} \mathrm{por} \mathrm{Müller} \mathrm{(2000)}$ com pastagens de capim mombaça irrigadas. Essa maior produtividade foi decorrente das condições climáticas mais favoráveis ao crescimento da planta forrageira nesse trabalho, que foi desenvolvido no oeste da Bahia.

Os resultados de produtividade obtidos em ambos os experimentos se encontram na faixa entre 1600 e $2000 \mathrm{~kg} \mathrm{PV/ha*ano,} \mathrm{apontada} \mathrm{por} \mathrm{Corsi} \mathrm{\&}$ Santos (1995) como sendo a meta de produtividade a ser atingida em pastagens de Panicum maximum.

\subsection{Conclusões}

O desempenho animal obtido nas pastagens adubadas intensivamente, 0,553 kg GPD, foi satisfatório e possibilitaria abater os animais em média aos 24 meses de idade. As variações de desempenho entre os períodos experimentais foram acompanhadas de alterações nas características estruturais da planta forrageira. 
A irrigação só possibilitou incremento na taxa de lotação na transição entre os períodos de "seca" e "águas". As taxas de lotação médias anuais nos dois experimentos foram muito semelhantes não confirmando o potencial da irrigação de pastagens no incremento da taxa de lotação.

A diferença de produtividade animal foi minimizada pelo maior desempenho animal do experimento sem irrigação em alguns períodos, demonstrando a importância desse componente na definição da produtividade quando as taxas de lotação são elevadas. Os resultados obtidos corroboram o potencial de geração de elevadas produtividades por pastagens adubadas intensivamente. 


\section{VIABILIDADE ECONÔMICA DA RECRIA E ENGORDA DE BOVINOS EM PASTAGENS ADUBADAS INTENSIVAMENTE COM E SEM O USO DA IRRIGAÇÃO}

\section{Resumo}

Pastagens adubadas intensivamente com irrigação e em sequeiro foram comparadas quanto à viabilidade econômica por meio de simulações determinísticas e estocásticas. A análise de viabilidade sem a consideração de risco apresentou resultados de lucro líquido, taxa de retorno sobre o ativo e taxa interna de retorno, respectivamente de $R \$$ - 164,91 por hectare, - 1,0\% e $6,1 \%$, para o sistema irrigado e $\mathrm{R} \$ 574,90$ por hectare, $4,4 \%$ e $17,2 \%$ para o em sequeiro. Contudo, essa análise subestimou os resultados dos indicadores de viabilidade econômica em ambos os sistemas. A análise de risco apontou o sistema irrigado como de baixíssima probabilidade de viabilidade econômica, enquanto para o sistema sem irrigação a probabilidade de um resultado econômico que apontasse inviabilidade foi baixa.

\section{Summary}

Highly fertilized pastures with and without irrigation were compared about economic viability using deterministic and stochastic simulations. The analysis without risk consideration showed results of net margin, simple rate of return 
and internal rate of return, respectively of $R \$-164,91$ per hectare, - 1,0\% and $6,1 \%$ for irrigated system, and $\mathrm{R} \$ 574,90$ per hectare, $4,4 \%$ and $17,2 \%$ for nonirrigated one. Deterministic analysis sub estimated the results of economic viability indicators. Risk analysis showed weak probability of economic viability for irrigated system. Non-irrigated system with high levels of fertilizer application indicated weak probability for not been an economical activity.

\subsection{Introdução}

A adubação intensiva de pastagens tem se tornado a opção freqüentemente utilizada para 0 incremento da produtividade pecuária em regiões de terras valorizadas. Nessas regiões a pecuária extensiva se mostra incapaz de competir em termos de resultados econômicos com outras alternativas de uso da terra, fato que pode ser comprovado pela substituição gradativa de áreas de pastagens por culturas agrícolas. Entre 1992 e 2001 a área de pastagens no estado de São Paulo foi reduzida em 165 mil hectares, enquanto as áreas de cana-de-açúcar e de citros cresceram respectivamente 950 mil e 128 mil hectares (IEA, 1994 e 2002).

Questionamentos quanto à viabilidade econômica da adubação intensiva de pastagens existem desde longa data. Gomide (1984) concluiu com base em experimentos de curva de resposta à adubação nitrogenada, não ser viável a adubação com nitrogênio (100 kg/ha) em pastagens destinadas à engorda de novilhos, considerando os preços desse insumo e da arroba do boi gordo vigentes na época. Mais recentemente, Esteves (2000) comparou os resultados econômicos da adubação intensiva de pastagens em relação à exploração extensiva apontando resultados muito superiores para os primeiros.

As respostas econômicas ao uso da adubação intensiva se mostram variáveis, como se pode esperar tendo em vista a ampla gama de fatores envolvidos na determinação do resultado econômico final. Tosi (1999) obteve lucro líquido de U\$\$ 530 (US\$1 = R \$1,07) por hectare na recria e engorda de 
novilhos canchim em pastagens de capim tanzânia adubadas com $320 \mathrm{~kg}$ $\mathrm{N} / \mathrm{ha}$ *ano. Esteves (2000) obteve lucro líquido por hectare de $\mathrm{R} \$ 445,50 \mathrm{com}$ a utilização de $300 \mathrm{~kg} \mathrm{~N} / \mathrm{ha}^{*}$ ano, também em pastagens de capim tanzânia destinadas àrecria e engorda de novilhos. Aguiar et al. (2001a) obtiveram lucro líquido de $R \$ 425,00$ por hectare quando pastagens de capim tanzânia foram adubadas com $360 \mathrm{~kg} \mathrm{~N} / \mathrm{ha}$. Lugão (2001), avaliando a resposta de Panicum maximum (acesso BRA - 006998) a diferentes níveis de adubação nitrogenada (0, 150, 300 e $450 \mathrm{~kg} \mathrm{~N} / \mathrm{ha}$ ) durante o período das águas, obteve máximo lucro por hectare $(R \$ 550,00)$ com $419 \mathrm{~kg} \mathrm{~N} / \mathrm{ha}$.

Os resultados econômicos da irrigação aliada à adubação como estratégia de intensificação do uso de pastagens ainda são escassos. Pinheiro (2002), através de modelos de simulação, obteve, para diferentes regiões do país, os resultados econômicos esperados com a intensificação em pastagens irrigadas e em sequeiro. A máxima taxa interna de retorno com a irrigação $(9,37 \%)$ foi obtida na região de Porto Nacional - TO, sendo de $12,40 \%$ a taxa correspondente àpastagem de sequeiro nessa mesma região.

Embora a determinação dos indicadores de viabilidade, como os apresentados nos trabalhos acima, seja de vital importância para a avaliação econômica, é inegável que esses sempre estão sujeitos a riscos e incertezas que podem alterar o resultado econômico final previsto. O pecuarista nunca tem o conhecimento completo da relação entre os fatores de produção e a produtividade e sobre os preços envolvidos na tomada de decisão. Assim, análises de risco dos resultados econômicos são instrumentos imprescindíveis na avaliação econômica, possibilitando uma estimativa numérica dos riscos envolvidos na estratégia de intensificação.

Boehlje \& Eidman (1984) dividiram os riscos da atividade agropecuária em duas classes: risco do preço e risco de produção. Todos os fatores que acarretam numa imprevisibilidade na oferta e demanda dos insumos e dos produtos finais, causando conseqüente variação nos seus valores monetários, são fontes de risco de preço. As variações no nível de produção resultantes de 
fatores não controláveis, como clima, pragas e variações genéticas, são as fontes de risco de produção.

A análise de risco com o uso de técnicas de simulação permite a obtenção de uma representação realista da resposta econômica de uma atividade. Esse recurso vem sendo utilizado em análises envolvendo o risco de preço de diferentes atividades agropecuárias: confinamento de bovinos de corte (Peres \& Mattos, 1990; Barione, 2002), citricultura (Azevedo Filho, 1988; Brunelli, 1990) e heveicultura (Takitane, 1988). A simulação permite ainda a previsão de fenômenos meteorológicos os quais são fontes de risco de produção (Sousa, 1999). A utilização de técnicas de simulação permite uma análise realmente abrangente dos possíveis resultados econômicos de um sistema de produção quando se combinam as duas possibilidades, a análise dos riscos de preço e de produção (Andrade Júnior, 2000; Souza, 2001).

O método de "Monte Carlo" se destaca como técnica de simulação por permitir a obtenção da distribuição de probabilidades de um dado indicador de viabilidade econômica, em função do comportamento das variáveis mais relevantes na determinação do fluxo de caixa. Segundo Hertz (1964) citado por Noronha (1981) a simulação pelo Método de Monte Carlo é constituída de quatro etapas: na primeira, as variáveis que definem o fluxo de caixa devem ter definidas suas distribuições de probabilidade; na segunda, valores dessas variáveis devem ser "sorteados" em cada distribuição de probabilidade; na terceira etapa, os valores "sorteados" devem ser utilizados na obtenção do fluxo de caixa do projeto e dos indicadores econômicos relevantes; enquanto na quarta etapa, após a repetição das etapas 2 e 3 por um bom número de vezes, os valores obtidos e armazenados são utilizados para a obtenção da distribuição de probabilidade do indicador de viabilidade.

Embora o avanço da informática tenha possibilitado o desenvolvimento de softwares capazes de efetuar análises de risco com relativa facilidade, até o momento os trabalhos dedicados à análise de viabilidade econômica da adubação intensiva de pastagens a fazem constantemente de maneira 
determinística. Dessa forma, esse trabalho é dedicado a comparação dos resultados econômicos da recria e engorda de bovinos em pastagens adubadas intensivamente com e sem o uso da irrigação, levando em consideração os riscos envolvidos na atividade.

\subsection{Material e métodos}

Os resultados produtivos utilizados nas simulações de análise de viabilidade econômica são apresentados na tabela 1 e já foram discutidos no capítulo 3 do presente trabalho. Maiores detalhes relacionados à condução dos experimentos podem ser obtidos nesse mesmo capítulo.

Tabela 1. Resultados produtivos obtidos com a adubação intensiva de pastagens com e sem o uso da irrigação.

\begin{tabular}{lcc}
\hline \multicolumn{1}{c}{ Resultado produtivo } & Com irrigação & Sem irrigação \\
Taxa de lotação anual (UA/ha) & 5,9 & 5,6 \\
Taxa de lotação "águas"1 (UA/ha) & 8,0 & 8,0 \\
Taxa de lotação "seca"² (UA/ha) & 2,8 & 2,4 \\
Desempenho animal anual (kg GPD) & 0,49 & 0,61 \\
Desempenho animal "águas" (kg GPD) & 0,49 & 0,58 \\
Desempenho animal "seca" (kg GPD) & 0,51 & 0,66 \\
Produtividade anual (kg PV/ha) & 1.628 & 1.672 \\
\hline período de "águas": outubro a abril; & &
\end{tabular}

Tanto na simulação determinística quanto na análise de risco, foi considerada uma área hipotética de 102,95 hectares, buscando uma maior aproximação da realidade da exploração de pastagens intensivas no Brasil. Dessa forma, tanto as receitas como os custos utilizados na elaboração do fluxo 
de caixa levaram em consideração essa escala de produção. As considerações quanto a esses componentes são descritas nos itens a seguir.

\subsubsection{Receitas}

As receitas foram provenientes da venda de duas categorias animais em períodos diferentes: em abril, venda de novilhos com 10,4 arrobas no caso do sistema irrigado e 11,2 arrobas no caso do não irrigado, correspondentes ao excedente de animais em relação à capacidade de suporte das pastagens no período "seco"; e em setembro venda do restante dos animais, bois magros com 13,0 arrobas no caso do sistema irrigado e bois gordos com 14,5 arrobas no caso do não irrigado. A opção pela consideração da arroba de boi gordo no caso do sistema não irrigado deveu-se à proximidade dos animais desse sistema do peso de abate. Fato que deve ser considerado, entretanto, é que no ano da efetuação da análise ocorreu deságio entre a arroba do boi gordo e a arroba do boi magro.

Todas as cotações consideradas na análise de viabilidade foram obtidas junto ao banco de dados do Centro de Estudos Avançados em Economia Aplicada (CEPEA - ESALQ/USP).

\subsubsection{Custos}

A estrutura de cálculo dos custos de produção baseourse na adaptação do método convencional descrito por Turra (1990), com a divisão dos custos em fixos e variáveis.

\section{Custos variáveis}

Nos custos variáveis foram computadas despesas relativas a: sal mineral, vermífugos, vacinas, medicamentos, fertilizantes, operações mecanizadas, manutenção de cercas, assistência técnica (consultoria), mão-deobra e compra de animais. A maior parte dos custos foi obtida junto à 
contabilidade do projeto, muito embora alguns custos tenham sido obtidos em publicações técnicas especializadas.

No sistema não irrigado foram adquiridos animais com 7,1 arrobas enquanto no sistema irrigado foram adquiridos animais com 6,9 arrobas. As cotações utilizadas para a definição das despesas com aquisição de animais foram obtidas junto ao CEPEA - ESALQ/USP.

No sistema com irrigação foram computados ainda os custos relativos à energia elétrica calculados seguindo método proposto por Franke \& Dorfman (1998) e manutenção do equipamento de pivô central (3\% a.a. do custo de aquisição do equipamento).

\section{Custos fixos}

Foram incluídos como custos fixos as depreciações de pastagens e infraestrutura (cercas, cochos de sal e bebedouros), além da depreciação do equipamento de pivô central no caso do sistema irrigado. As depreciações foram calculadas pelo método linear (Noronha, 1981) assumindo uma vida útil de dez anos para os ativos e um valor final de revenda correspondente a $20 \%$ do valor inicial do ativo.

Também compuseram os custos fixos os juros sobre o capital investido em terra, pastagens, infra-estrutura e no caso do sistema irrigado no equipamento de pivô central. No calculo do juro sobre o capital investido em terra, utilizou-se o valor do arrendamento da área para a produção de cana-deaçúcar (12,4 tha) como o seu custo de oportunidade, sendo esse valor de $R \$$ 310,29 por hectare ao ano (Instituto de Economia Agrícola, 2002). Para os juros sobre o capital investido em infra-estrutura e pastagens utilizou-se o valor de 6 $\%$ a.a. como custo de oportunidade. O juro sobre o capital investido no equipamento de pivô central foi calculado conforme proposta de Franke \& Dorfman (1998).

Além dos componentes supracitados, custos relativos à administração e impostos também foram enquadrados como fixos. 


\subsubsection{Investimentos iniciais}

Como investimentos iniciais foram consideradas despesas relativas a: implantação de infraestrutura (cercas, cochos de sal e bebedouros), estabelecimento da pastagem e no caso do sistema irrigado do sistema de irrigação. As despesas relacionadas à implantação de infraestrutura são apresentadas na tabela 2 e foram obtidas numa publicação especializada (Anualpec, 2002). O custo de implantação da pastagem no ano de implantação do projeto (1999) foi corrigido para 2001 com base no IGP-DI e utilizado na análise, sendo esse de $R \$ 803,53$ por hectare. O custo do sistema de irrigação utilizado, incluindo equipamentos de irrigação e bombeamento, abertura de valetas, casa de bombeamento, base do pivô central e rede elétrica, foi obtido em Pinheiro (2002), sendo esse de $\mathrm{R} \$ 2.614$ por hectare.

O valor da terra utilizado na análise foi obtido junto ao IEA (2002), sendo esse de $\mathrm{R} \$ 5.475$ por hectare, referente a terras de cultura de primeira.

Tabela 2. Custos referentes àimplantação da infraestrutura.

\begin{tabular}{lcccc}
\hline \multicolumn{1}{c}{ Discriminação } & Unidade & Custo (R\$/un) & Quantidade & $\begin{array}{c}\text { Custo Total } \\
\text { (R\$) }\end{array}$ \\
\hline Cercas convencionais & $\mathrm{Km}$ & $2.182,24$ & 3,6 & $7.847,34$ \\
Cercas elétricas & $\mathrm{Km}$ & 686,25 & 6,9 & $4.715,46$ \\
Bebedouros & - & $2.200,00$ & 2 & $4.400,00$ \\
Cochos de sal & $\mathrm{M}$ & 60,00 & 50 & $3.000,00$ \\
Total & - & - & - & $\mathbf{1 9 . 9 6 2 , 7 9}$ \\
\hline
\end{tabular}

\subsubsection{Elaboração do fluxo de caixa}

Com base nos investimentos iniciais necessários em cada um dos dois sistemas e nas receitas e despesas obtidas anualmente, elaborou-se uma série de fluxos de caixa considerando um horizonte de dez anos. Dada a defasagem temporal entre os fluxos de entrada e de saída num mesmo ano, adicionou-se 
ao fluxo de caixa do primeiro ano um capital de giro correspondente a $40 \%$ dos custos variáveis do segundo ano, sendo esse recuperado como valor residual no último ano do projeto, conforme sugestão de Noronha (1981).

Todos os custos foram considerados constantes ao longo dos anos do projeto, de modo que foi desconsiderado o efeito da inflação sobre os preços. Assim os valores das taxas internas de retorno calculados são valores reais e não nominais, devendo assim ser comparados com o custo de oportunidade do capital também real.

\subsubsection{Forma de análise dos resultados}

A análise econômica determinística consistiu na determinação com base na série de fluxos de caixa de cada sistema dos indicadores: custo operacional, custo total, custo por arroba produzida e total, lucro líquido, taxa de retorno sobre o ativo, valor presente líquido, taxa interna de retorno e período para pagamento do investimento ("pay-back"econômico).

Após a obtenção dos indicadores de viabilidade econômica de forma determinística, foi efetuada a análise de risco para a obtenção da distribuição de probabilidade acumulada dos indicadores lucro líquido, taxa de retorno sobre o ativo e taxa interna de retorno. Essa análise foi efetuada através de simulação pelo Método de "Monte Carlo" com o auxílio do software @Risk 4.5 тм 2 (Palisade, 2002).

\subsection{Resultados e Discussão}

A tabela 3 refere-se à composição dos custos anuais de produção nos sistemas irrigado e sem irrigação. Em ambos os sistemas a aquisição de animais apresentou a maior participação dentre os componentes do custo de

2 @Risk é um add-in para Microsoft Excel desenvolvido e comercializado pela Palisade Corporation New Field - NY - USA. 
produção, respectivamente $71,8 \%$ e $78,7 \%$ para os sistemas irrigado e em sequeiro. As despesas relativas a fertilizantes também se destacaram na composição dos custos de produção correspondendo a 9,8\% dos custos no sistema irrigado e 9,3\% no não irrigado. A maior participação percentual dos custos relativos a depreciação no sistema irrigado $(3,9 \%)$ em relação ao sem irrigação $(1,2 \%)$, se deve à depreciação do equipamento de irrigação. Os gastos com energia elétrica no sistema com irrigação corresponderam a 2,4\% dos custos de produção. 
Tabela 3. Composição dos custos anuais de produção nos sistemas irrigado e sem irrigação.

\begin{tabular}{|c|c|c|c|c|}
\hline \multirow{3}{*}{ Componente } & \multicolumn{2}{|l|}{ Trrigado } & \multicolumn{2}{|c|}{ Não } \\
\hline & & & \multicolumn{2}{|l|}{ irrigado } \\
\hline & \multicolumn{2}{|l|}{$R \boldsymbol{R}$} & $\mathbf{R} \$$ & $\%$ \\
\hline \multicolumn{5}{|l|}{ Custos Variáveis } \\
\hline Sal mineral & $11.414,89$ & 1,5 & $10.354,86$ & 1,5 \\
\hline Vermífugos & $4.312,83$ & 0,6 & $4.114,68$ & 0,6 \\
\hline Vacinas & $2.203,23$ & 0,3 & $1.998,63$ & 0,3 \\
\hline Medicamentos & $1.836,03$ & 0,2 & $1.665,53$ & 0,2 \\
\hline Fertilizantes & $75.229,68$ & 9,8 & $64.471,41$ & 9,3 \\
\hline Hora-máquina & $2.539,83$ & 0,3 & $2.177,00$ & 0,3 \\
\hline Energia elétrica & $18.581,72$ & 2,4 & - & - \\
\hline Manutenção de cercas & 724,26 & 0,1 & 724,26 & 0,1 \\
\hline Manutenção do pivô & $8.073,35$ & 1,1 & - & - \\
\hline Compra de animais & $551.843,34$ & 71,8 & $542.619,51$ & 78,7 \\
\hline Consultoria & $3.300,00$ & 0,4 & $3.300,00$ & 0,5 \\
\hline Mão-de-obra & $9.720,00$ & 1,3 & $9.720,00$ & 1,4 \\
\hline \multicolumn{5}{|l|}{ Custos fixos } \\
\hline Administração, impostos e outros & $2.134,99$ & 0,3 & $2.134,99$ & 0,3 \\
\hline Depreciações & $29.743,87$ & 3,9 & $8.214,95$ & 1,2 \\
\hline Juros sobre o capital investido & $47.005,02$ & 6,1 & $38.105,57$ & 5,5 \\
\hline Custo Total & $768.663,05$ & 100 & $689.601,39$ & 100 \\
\hline
\end{tabular}

A composição percentual dos custos de produção na adubação intensiva de pastagens já foi abordada por outros trabalhos como os de Tosi (1999), Esteves (2000) e Lugão (2001). As diferenças observadas entre as composições apresentadas nesses trabalhos e a do sistema não irrigado são justificadas pela inclusão de diferentes componentes na análise de custo de cada um. Tosi (1999) não considerou na composição relativa dos custos de 
produção as despesas referentes à aquisição de animais, depreciações e remuneração sobre o capital investido em terra. Esteves (2000) considerou em sua análise os custos relativos a depreciações e remuneração sobre o capital investido em animais e sobre o custeio, embora não considerasse o custo de oportunidade da terra e as despesas relativas à aquisição de animais. Lugão (2001) por sua vez, embora tenha considerado depreciações e remuneração sobre o capital investido em terra, não incluiu as despesas com aquisição de animais. Contudo, a composição percentual dos custos de produção no sistema sem irrigação quando são excluídas as despesas com aquisição de animais se aproxima das apresentadas por Esteves (2000) e Lugão (2001).

Outro fato que contribui para as diferenças entre a composição apresentada por Tosi (1999) e a do sistema não irrigado, é que em Tosi (1999) todos os custos foram apresentados em dólares americanos num período em que a havia praticamente paridade entre o dólar e o real (1 US $\$=R \$ 1,07$ ). Tendo em vista que durante o ano em que foi efetuada a análise econômica do sistema não irrigado a taxa de câmbio foi consideravelmente diferente (1 US\$ = $R \$ 2,57)$ e que alguns insumos utilizados na adubação intensiva de pastagens têm seus preços praticamente indexados ao dólar (e.g. fertilizantes), a comparação pura e simples da composição percentual dos custos de produção dos dois trabalhos deve ser feita com ressalvas.

Os indicadores custo operacional, custo total, custo por arroba produzida e custo por arroba total são apresentados na tabela 4. Os valores obtidos foram consideravelmente maiores para o sistema com irrigação. A diferença relativa ao custo operacional deveu-se principalmente æ̀s despesas com energia elétrica e fertilizantes. Enquanto no sistema irrigado a adubação foi de $500 \mathrm{~kg}$ de N/ha, no sistema não irrigado essa foi de $430 \mathrm{~kg}$ de N/ha, daí a diferença dos custos com fertilizantes. Além disso, as despesas relativas à depreciação e remuneração sobre o capital investido no sistema de irrigação, e a maior despesa com aquisição de animais, acarretaram num maior custo total para o sistema irrigado. Embora os custos totais fossem superiores nesse sistema, 
isso não refletiu numa maior produtividade, o que conseqüentemente elevou os custos por arroba produzida e por arroba total no sistema com irrigação em comparação ao em sequeiro.

Tabela 4. Custo operacional, custo total, custo por arroba produzida e custo por arroba total nos sistemas com e sem irrigação.

\begin{tabular}{lcc}
\hline \multicolumn{1}{c}{ Indicador } & Irrigado & Não irrigado \\
\hline Custo operacional $(\mathrm{R} \$ / \mathrm{ha}){ }^{1}$ & $1.339,83$ & 957,03 \\
Custo total $(\mathrm{R} \$ / \mathrm{ha})$ & $7.466,37$ & $6.698,41$ \\
Custo por arroba produzida $(\mathrm{R} \$ / @)^{2}$ & 38,81 & 25,62 \\
Custo por arroba total $(\mathrm{R} \$ / @)^{3}$ & 50,03 & 44,92 \\
${ }^{1}$ Custos variáveis descontando o custo de aquisição dos animais; \\
${ }^{2}$ Custo total sem considerar o custo de aquisição dos animais, dividido pelo número de arrobas \\
produzidas anualmente; \\
${ }^{3}$ Custo total considerando o custo de aquisição de animais, dividido pelo número de arrobas \\
vendidas anualmente.
\end{tabular}

O custo operacional do sistema sem irrigação ( $R \$ 957,03$ por ha) foi inferior ao obtido por Aguiar et al. (2001a), R\$1.049 por hectare, na recria e engorda de bovinos em pastagens de capim tanzânia adubadas com $360 \mathrm{~kg}$ $\mathrm{N} / \mathrm{ha}$, muito embora se esperasse o contrário, uma vez que aquele custo era referente ao período de outubro de 1999 a novembro de 2000. Naquele mesmo trabalho, o custo total foi de $\mathrm{R} \$ 5.323$ por hectare, com custo por arroba produzida de $\mathrm{R} \$ 29$. O maior custo por arroba produzida pode ser justificado também pela menor produtividade obtida nesse trabalho (40@) quando comparada àprodutividade do sistema sem irrigação (55,7@).

Demais resultados de literatura relacionados aos custos de produção da recria e engorda de bovinos em pastagens adubadas intensivamente fazem a avaliação apenas parcial do sistema de produção, considerando somente o período de "águas". Lugão (2001) obteve custo operacional no período de outubro 1998 a abril de 1999 de $\mathrm{R} \$ 783$ por hectare, em pastagens de Panicum 
maximum (BRA-006998) adubadas com $450 \mathrm{~kg} \mathrm{~N} / \mathrm{ha}$. Aguiar et al. (2002b) obteve custo operacional no período de novembro 2000 a abril de 2001 de $R \$$ 1.210 por hectare em pastagens de capim tanzânia adubadas com 533 kg N/ha.

Os indicadores lucro líquido e taxa de retorno sobre o ativo dos dois sistemas são apresentados na tabela 5 . As despesas totais anuais no sistema irrigado suplantaram as receitas, de maneira que no balanço entre esses componentes houve prejuízo de $\mathrm{R} \$ 164,91$ por hectare, o que demonstra claramente que a irrigação de pastagens no ano experimental não se constituiu numa alternativa economicamente viável. Os resultados do sistema não irrigado foram superiores com lucro líquido de $R \$ 574,39$ e taxa de retorno sobre o ativo de $4,4 \%$.

Tabela 5. Lucro líquido e taxa de retorno sobre o ativo nos sistemas com e sem irrigação.

\begin{tabular}{lcc}
\hline \multicolumn{1}{c}{ Indicador } & Irrigado & Não irrigado \\
\hline Lucro líquido $(\mathrm{R} \$ / \mathrm{ha})$ & $-164,91$ & 574,90 \\
Taxa de retorno sobre o ativo (\%) & $-1,0$ & 4,4 \\
\hline
\end{tabular}

O lucro líquido no sistema em sequeiro foi superior aos resultados de Aguiar et al. (2001a), que obteve $R \$ 425$ por hectare, com taxa de retorno sobre o ativo de 8,0\%. O valor da terra tem grande influência na taxa de retorno sobre o ativo, como atestam os resultados de simulação apresentados por Balsalobre et al. (2002). O valor da terra considerado na análise do presente trabalho, $R \$$ 5.475 por hectare, provavelmente foi muito superior ao considerado por Aguiar et al. (2001a), daí a grande diferença entre os trabalhos quanto à taxa de retorno sobre o ativo, embora os valores de lucro líquido sejam próximos.

A análise dos indicadores valor presente líquido, taxa interna de retorno e "pay-back" econômico, permite uma avaliação mais apropriada dos resultados econômicos de uma alternativa de investimento por considerarem a dimensão do dinheiro no tempo, fato não considerado pelos demais indicadores de 
avaliação econômica apresentados até o momento. Um investidor somente trocará um ativo de maior liquidez - dinheiro - por outros ativos quaisquer, se a expectativa de reconversão futura desses ativos resultar num montante de dinheiro superior ao existente no momento inicial, considerando-se um ambiente no qual a moeda tem poder aquisitivo constante, daí a consideração desses indicadores apresentados na tabela 6.

Tabela 6. Valor presente líquido (VPL), taxa interna de retorno (TIR) e "payback" econômico (PBE) dos sistemas.

\begin{tabular}{lcc}
\hline \multicolumn{1}{c}{ Indicador } & Irrigado & Não írrigado \\
\hline $\mathrm{VPL}(\mathrm{R} \$)^{1}$ & $-375.060,36$ & $236.541,92$ \\
$\mathrm{TIR}(\%)$ & $-6,1 \%$ & $17,2 \%$ \\
$\mathrm{PBE}{ }^{1}$ & $*$ & 3 \\
\hline & & \\
\hline
\end{tabular}

* o projeto é incapaz de recuperar os investimentos iniciais realizados visto que o resultado do fluxo de caixa anual é negativo.

O valor presente líquido negativo e a taxa interna de retorno inferior ao custo de oportunidade do capital no sistema irrigado demonstram sua inviabilidade econômica nas condições determinísticas da análise. De maneira contrária, o sistema não irrigado mostrou-se viável economicamente, visto que sua taxa interna de retorno foi superior a $6 \%$ a.a., valor considerado como 0 custo de oportunidade do capital. Enquanto no sistema irrigado não seria possível a recuperação dos investimentos iniciais realizados, no sistema sem irrigação, essa recuperação se daria em 3 anos.

Esteves (2000) obteve taxa interna de retorno de $29,6 \%$ na recria e engorda de bovinos em pastagens adubadas intensivamente, resultado superior ao obtido no sistema não irrigado (17,2\%). Contudo na análise de Esteves (2000) não foi considerado o custo de oportunidade da terra, o que acarretou em superestimativa dos resultados obtidos. 
Estrada \& Paladines (1979) analisaram os resultados econômicos da engorda de bovinos em pastagens adubadas e irrigadas na Colômbia, tendo obtido produtividade de $1.072 \mathrm{~kg} \mathrm{PV} / \mathrm{ha}{ }^{*}$ ano, com taxa interna de retorno de $5,4 \%$. O resultado bem diferente do obtido na análise do sistema irrigado esteve relacionado a particularidades da pecuária colombiana na época. As relações entre o custo dos fatores de produção e o preço de venda do boi gordo se distanciaram muito das consideradas para a análise do sistema irrigado, o que justifica a divergência de resultados.

Estudando a viabilidade econômica da recria de bovinos em pastagens irrigadas em diferentes regiões do Brasil por meio de modelos de simulação, Pinheiro (2002) apontou como resultado esperado para Piracicaba-SP, taxa interna de retorno de $0,87 \%$, com lucro líquido anual de $\mathrm{R} \$ 48,86$ por hectare. Nesse trabalho, as simulações assumiram um desempenho animal de $0,75 \mathrm{~kg}$ GPD, adubação com $600 \mathrm{~kg}$ de $\mathrm{N} /$ ha e preço de $\mathrm{R} \$ 40$ para arroba do boi magro. A taxa de lotação obtida na simulação foi muito baixa quando comparada à efetivamente obtida no sistema irrigado, respectivamente 3,6 contra 5,9 UA/ha. Quando a análise foi feita para pastagem adubada intensivamente sem o uso da irrigação e assumindo as demais condições idênticas æ̀̀ da pastagem irrigada, a taxa interna de retorno foi de 1,3\% com lucro líquido de $R \$ 31,95$ por hectare, resultado muito aquém do obtido efetivamente no sistema não irrigado. Assim como na pastagem irrigada, os resultados produtivos apontados pela simulação de Pinheiro (2002) para a pastagem em sequeiro foram inferiores aos obtidos no sistema não irrigado, com taxa de lotação de 2,6 UA/ha no primeiro e 5,6 nesse último. A divergência de resultados produtivos e econômicos entre os trabalhos, aponta para a necessidade de validação do modelo utilizado por Pinheiro (2002) para a geração desses resultados.

Após a obtenção dos resultados de forma determinística, foi efetuada a análise de risco envolvendo tanto o risco de preço quanto de produção. As variáveis consideradas estocásticas foram: 
- Taxa de lotação das pastagens no período de "águas"

- Taxa de lotação das pastagens no período de "seca"

- Custo de aquisição dos animais de reposição: foram consideradas as cotações do garrote nelore entre 12 e 18 meses no mês de outubro;

- Preço de venda dos animais: representado pelo preço do boi magro nelore nos meses de abril e setembro e pela cotação da arroba do boi gordo em setembro;

- Custo do fertilizante nitrogenado: representado pelo custo da tonelada do sulfato de amônio. Dada a dificuldade da obtenção de uma série histórica com as cotações da fórmula de adubo efetivamente utilizada nos experimentos (26-03-00), o sulfato foi escolhido por ser o principal componente dessa fórmula.

- Custo de oportunidade da terra: calculado com base no preço da tonelada de cana-de-açúcar. Como a cana-de-açúcar é a principal cultura agrícola da região estudada, considerou-se como o custo de oportunidade da terra o arrendamento da área para a produção de cana com pagamento em espécie de 12,4 tha (30 t/alq) anualmente.

A análise seguiu com a determinação da função de distribuição de probabilidades de cada uma das variáveis supracitadas. As variáveis relacionadas ao risco de produção (taxas de lotação no período de "águas" e no período de "seca") tiveram suas funções de distribuição de probabilidades definidas de maneira subjetiva. Segundo Anderson et al. (1977), citado por Noronha (1981), a probabilidade subjetiva é definida como sendo o grau de crença ou grandeza de convicção que um indivíduo possui acerca da ocorrência de um fenômeno. Assim, consultores especializados em manejo de pastagens foram questionados quanto à suas expectativas de valores de taxa de lotação média, mínima e máxima, para os sistemas nos períodos de "águas" e "seca". Tais técnicos também foram questionados quanto à simetria da distribuição de freqüência de probabilidades dos valores de taxa de lotação. De posse dessas 
informações, foi ajustada uma função de distribuição que se aproximasse da média das expectativas dos consultores. Na elaboração do modelo para a simulação envolvendo risco, também foram consideradas taxas de lotação dos períodos de "águas" e "seca" $20 \%$ inferiores æ̀ estimativas dos consultores para os dois primeiros anos após a implantação das pastagens.

As variáveis relacionadas ao risco de preço (custo de aquisição dos animais de reposição, preço de venda dos animais, preço do fertilizante nitrogenado e custo de oportunidade da terra) tiveram suas funções de distribuição de probabilidade definidas de outra forma. Cotações referentes ao período compreendido entre 1995 e 2002 para o Estado de São Paulo, obtidas junto ao banco de dados do CEPEA - ESALQ/USP, foram atualizadas com base no IGP-DI para 0 ano de 2002. Essas cotações atualizadas foram analisadas com o recurso Best Fit do software @Risk ${ }^{\mathrm{TM}}$ (Palisade, 2002) para a determinação de suas funções de distribuição de probabilidade, sendo o teste do Qui-quadrado utilizado para a seleção da distribuição mais apropriada. A tabela 7 apresenta a função de distribuição de probabilidades utilizada para cada variável estocástica. 
Tabela 7. Função de distribuição de probabilidade utilizada na análise de risco em cada uma das variáveis estocásticas.

\begin{tabular}{lc}
\hline \multicolumn{1}{c}{ Cotação } & $\begin{array}{c}\text { Função de distribuição de } \\
\text { probabilidade }\end{array}$ \\
\hline Taxa de lotação nas "águas" & Pert (Beta) \\
Taxa de lotação na "seca" & Pert (Beta) \\
Custo do garrote & Beta General \\
Preço do boi magro em abril & Logística \\
Preço do boi magro em setembro & Log logística \\
Arroba do boi gordo & Beta General \\
Custo do sulfato de amônio & Valor extremo \\
Custo de oportunidade da terra & Logística \\
\hline
\end{tabular}

As variáveis estocásticas utilizadas na análise de risco foram verificadas quanto àindependência por meio de uma análise de correlação. Os coeficientes de correlação significativos são apresentados na tabela 8. Essas correlações foram então consideradas na análise de risco. 
Tabela 8. Coeficientes de correlação obtidos na análise de correlação entre as variáveis estocásticas estudadas.

\begin{tabular}{ccccc}
\hline & $\begin{array}{c}\text { Custo do } \\
\text { garrote }\end{array}$ & $\begin{array}{c}\text { Preço do boi } \\
\text { magro em } \\
\text { abril }\end{array}$ & $\begin{array}{c}\text { Preço do boi } \\
\text { magro em } \\
\text { setembro }\end{array}$ & $\begin{array}{c}\text { Preço da @ } \\
\text { do boi } \\
\text { gordo }\end{array}$ \\
\hline $\begin{array}{c}\text { Custo do garrote } \\
\text { Preço do boi } \\
\text { magro em abril }\end{array}$ & 0,75 & 0,75 & 0,94 & 0,9 \\
$\begin{array}{c}\text { Preço do boi } \\
\text { magro em }\end{array}$ & 0,94 & NS & $N^{1}$ & NS \\
setembro & & & 1 & 0,92 \\
$\begin{array}{c}\text { Preço da @ do } \\
\text { boi gordo }\end{array}$ & 0,9 & NS & & 1 \\
\hline
\end{tabular}

Os resultados médios de lucro líquido obtidos na análise de risco foram superiores aos obtidos de maneira determinística. Enquanto no sistema não irrigado o lucro líquido médio obtido no primeiro caso foi de $R \$ 765,24$ por hectare, na análise de viabilidade econômica sem a consideração do risco esse foi de $R \$ 574,90$ por hectare (figura 1). A probabilidade de ocorrência de um resultado de lucro líquido menor ou igual ao resultado da análise determinística foi de $35,08 \%$, enquanto a probabilidade de ocorrência de um resultado nulo ou negativo para esse indicador foi de apenas $5,14 \%$.

De maneira semelhante, o resultado médio de lucro líquido do sistema irrigado levando em consideração os riscos ( $R$ \$ 1,44 por hectare) foi superior ao obtido na análise sem essa consideração ( $R \$$ - 164,91) (figura 2). A probabilidade de ocorrência de um resultado de lucro líquido igual ou inferior ao obtido de maneira determinística foi de $36,44 \%$ enquanto a probabilidade de ocorrência de valores nulos ou negativos foi de $50,82 \%$. 


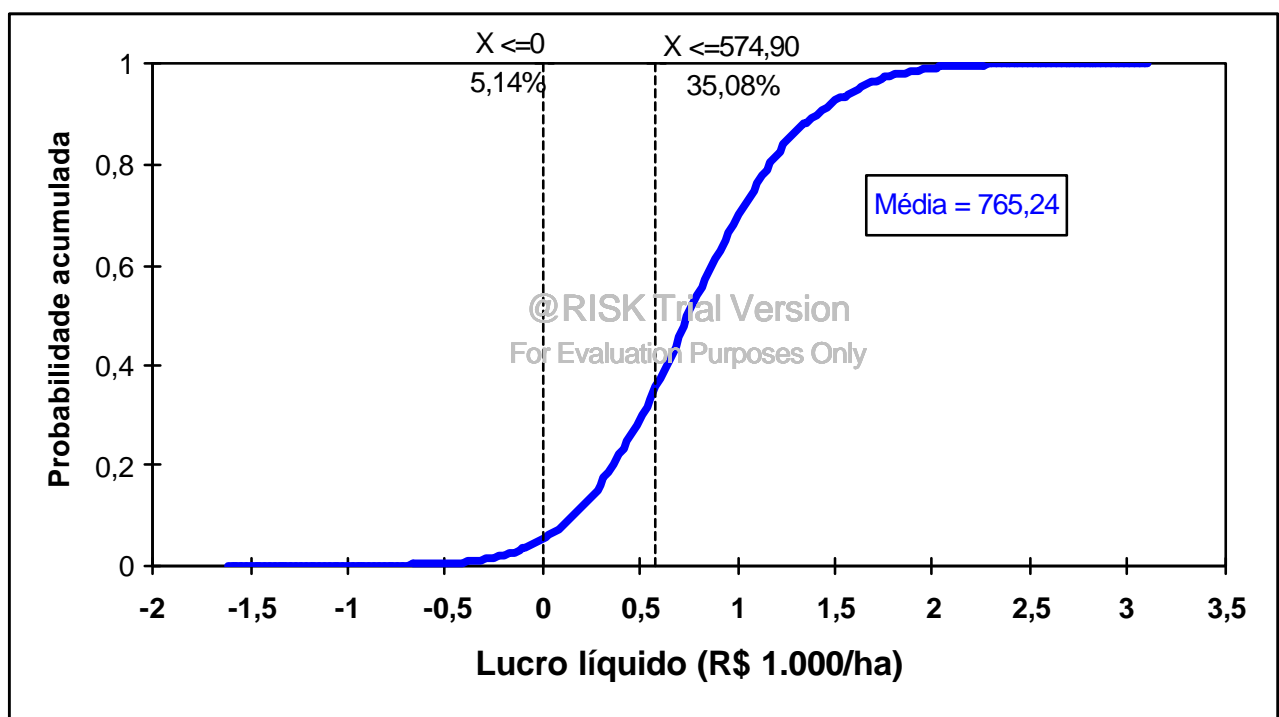

Figura 1 - Distribuição de probabilidade acumulada do lucro líquido ( $R \$$ 1.000/ha) para o sistema não irrigado.

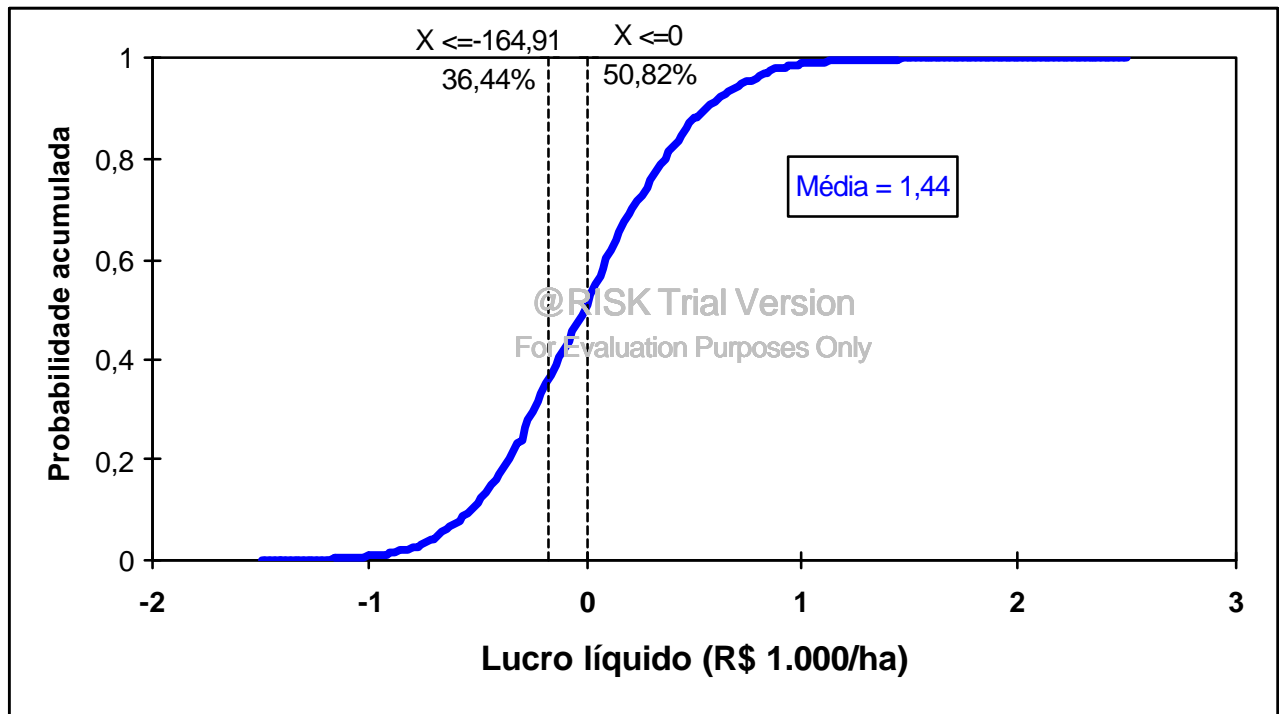

Figura 2 - Distribuição de probabilidade acumulada do lucro líquido ( $R \$$ 1.000/ha) para o sistema irrigado. 
Os resultados da análise de sensibilidade com o uso de regressão múltipla tipo "stepwise" entre os resultados de lucro líquido e as variáveis estocásticas de cada simulação, apontaram as variáveis custo do garrote e preço do boi magro em abril como as principais determinantes da variação nos resultados do indicador lucro líquido (figuras 3 e 4). $O$ valor de coeficiente $\beta$ padronizado de - 1,28 para a variável custo do garrote no sistema em sequeiro, implica que para cada aumento de uma unidade no desvio padrão do custo do garrote, ocorre uma redução de 1,28 unidade no desvio padrão do lucro líquido, considerando demais variáveis constantes. Os maiores coeficientes $\beta$ padronizados obtidos no sistema irrigado indicam que esse sistema é mais susceptível a variações do custo do garrote e do preço do boi magro do que o sistema sem irrigação. O custo dos animais de reposição e o preço de venda dos animais são, pois os principais determinantes do risco de preço na recria e engorda de bovinos em pastagens adubadas intensivamente, de modo que a implementação de estratégias que minimizem esse risco, como o "hedging" em mercados futuros, passa a ser importante para minimização de resultados econômicos desfavoráveis.

Fato que deve ser considerado, entretanto, é que em níveis mais baixos de produtividade outras variáveis que não apenas o custo de aquisição dos animais e o preço de venda ganham maior importância na definição do resultado econômico final do sistema de produção. 


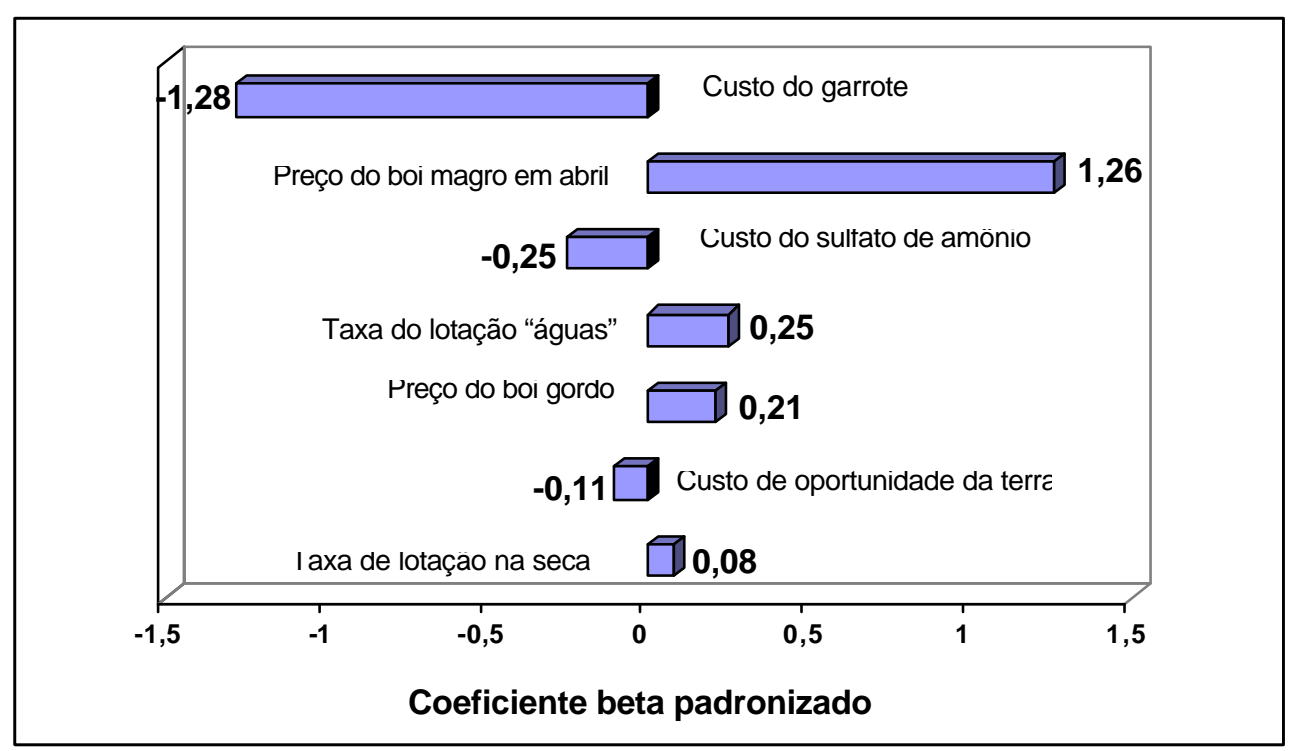

Figura 3 - Resultados da análise de sensibilidade para as variáveis estudadas na análise de risco no sistema não irrigado.

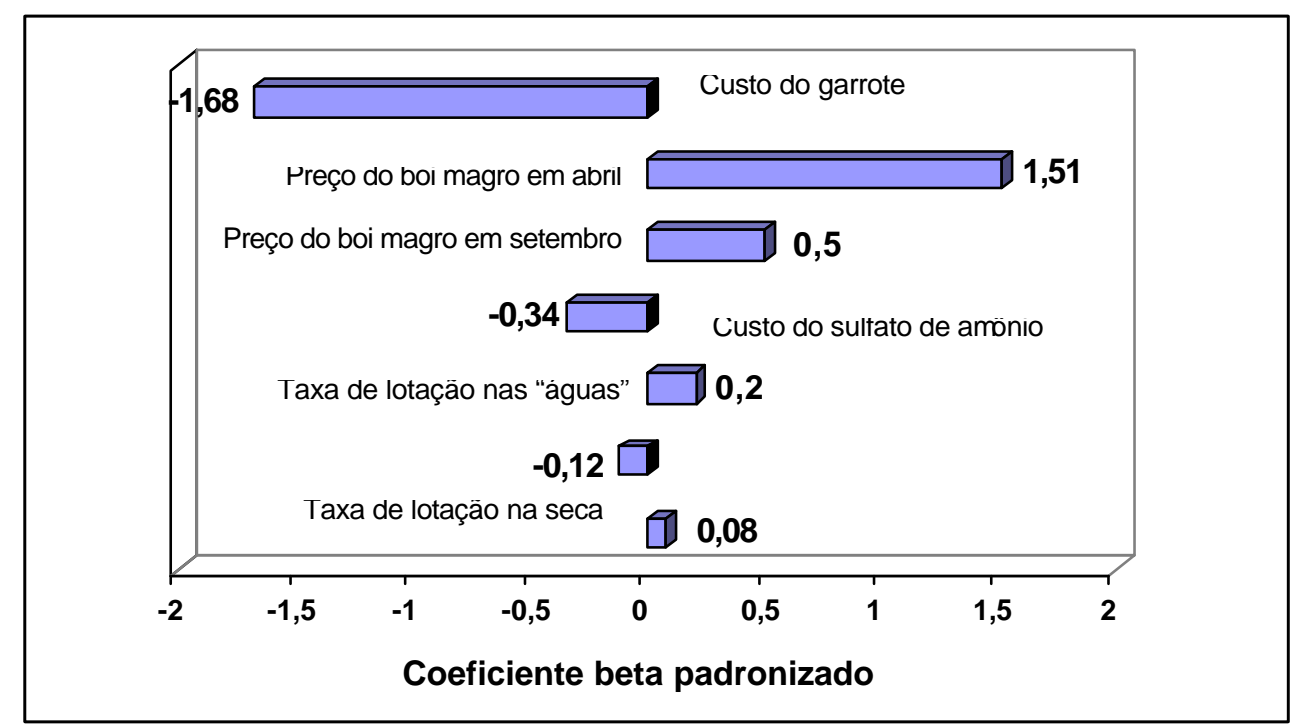

Figura 4 - Resultados da análise de sensibilidade para as variáveis estudadas na análise de risco no sistema irrigado. 
As figuras 5 e 6 são referentes aos resultados da análise de risco do indicador taxa de retorno sobre o ativo, respectivamente para o sistema em sequeiro e irrigado. No sistema sem irrigação, a probabilidade de um resultado de taxa de retorno sobre ativo menor ou igual ao valor obtido de maneira determinística $(4,4 \%)$ foi de $28,4 \%$, enquanto o resultado médio da análise de risco foi de $6,9 \%$. Ainda nesse sistema, a probabilidade de valores acima de $8,0 \%$ para esse indicador foi de $38,4 \%$.

No sistema irrigado o resultado médio de taxa de retorno sobre o ativo obtido na análise de risco foi superior ao obtido na análise determinística, respectivamente $0,007 \%$ e $-1,0 \%$. Contrastante com os resultados do sistema não irrigado, a probabilidade de um resultado superior a 8,0\% para a taxa de retorno sobre $o$ ativo foi de apenas $0,5 \%$.

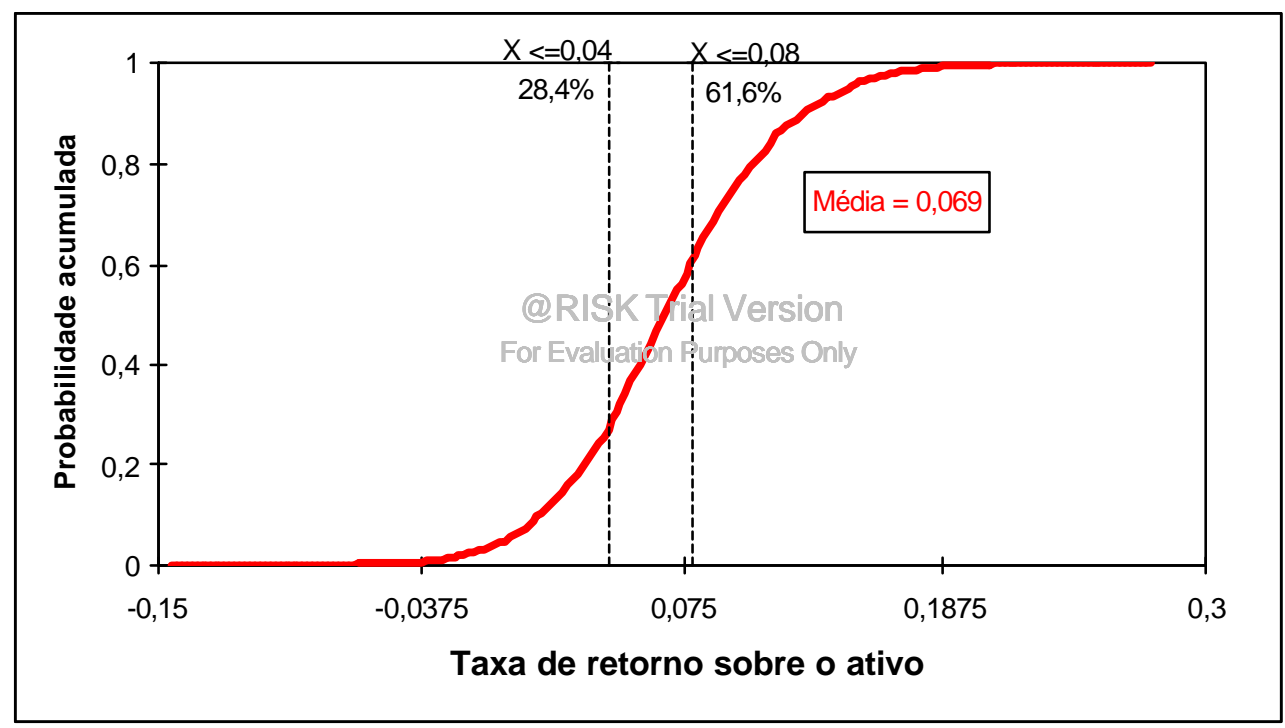

Figura 5 - Distribuição de probabilidade acumulada da taxa de retorno sobre 0 ativo para o sistema em sequeiro. 


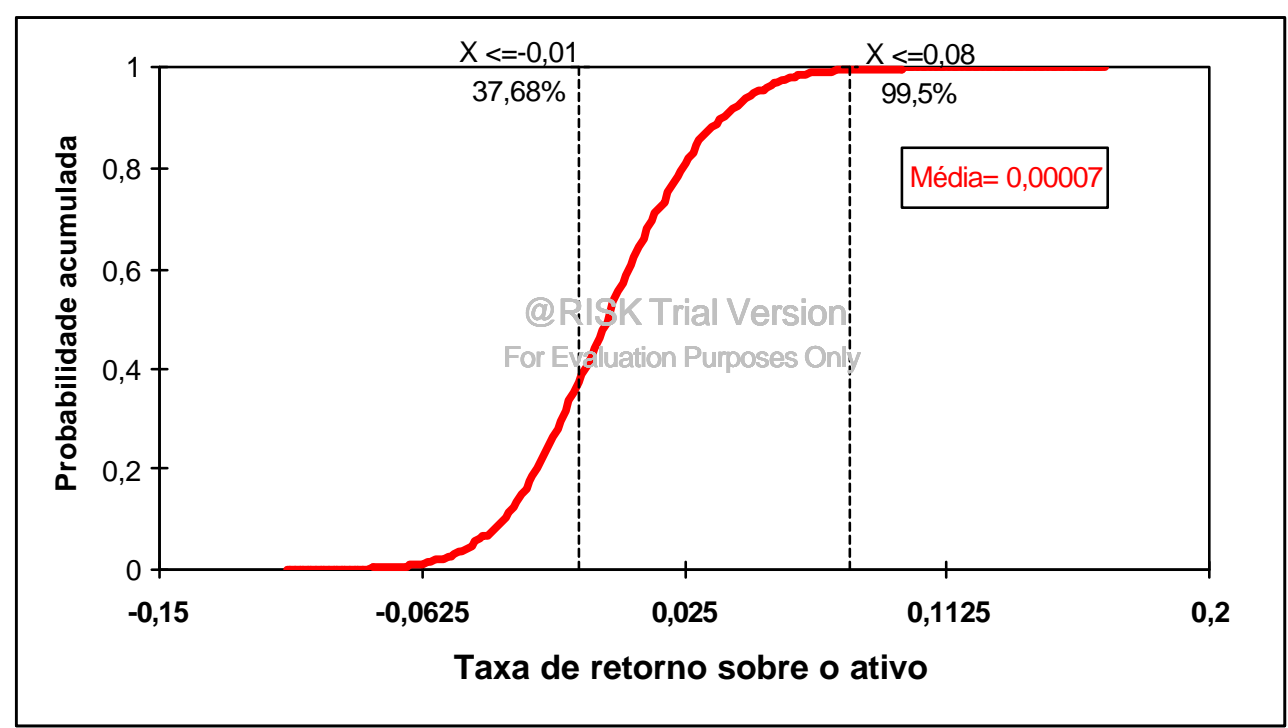

Figura 6 - Distribuição de probabilidade acumulada da taxa de retorno sobre 0 ativo para o sistema irrigado.

Os resultados da análise de risco do indicador taxa interna de retorno são apresentados nas figuras 7 e 8. A TIR média do sistema sem irrigação foi de $18,3 \%$, valor superior aos $17,2 \%$ obtidos na análise sem a consideração do risco. A probabilidade de ocorrência de um resultado menor ou igual a esse último foi de $41,26 \%$ e a probabilidade de um valor menor ou igual a $6,0 \%$, valor que indicaria inviabilidade econômica, foi de apenas $0,27 \%$.

Também no sistema irrigado a análise determinística subestimou os resultados de taxa interna de retorno. A TIR média obtida na análise de risco no sistema irrigado foi de $-2,8 \%$, contrastante com os $-6,1 \%$ obtidos na simulação determinística. A probabilidade de obtenção de um valor de TIR menor ou igual a esse último, bi de $12,59 \%$ enquanto a probabilidade de um valor acima de $6,0 \%$, que viabilizaria o sistema, foi de apenas $0,04 \%$. 


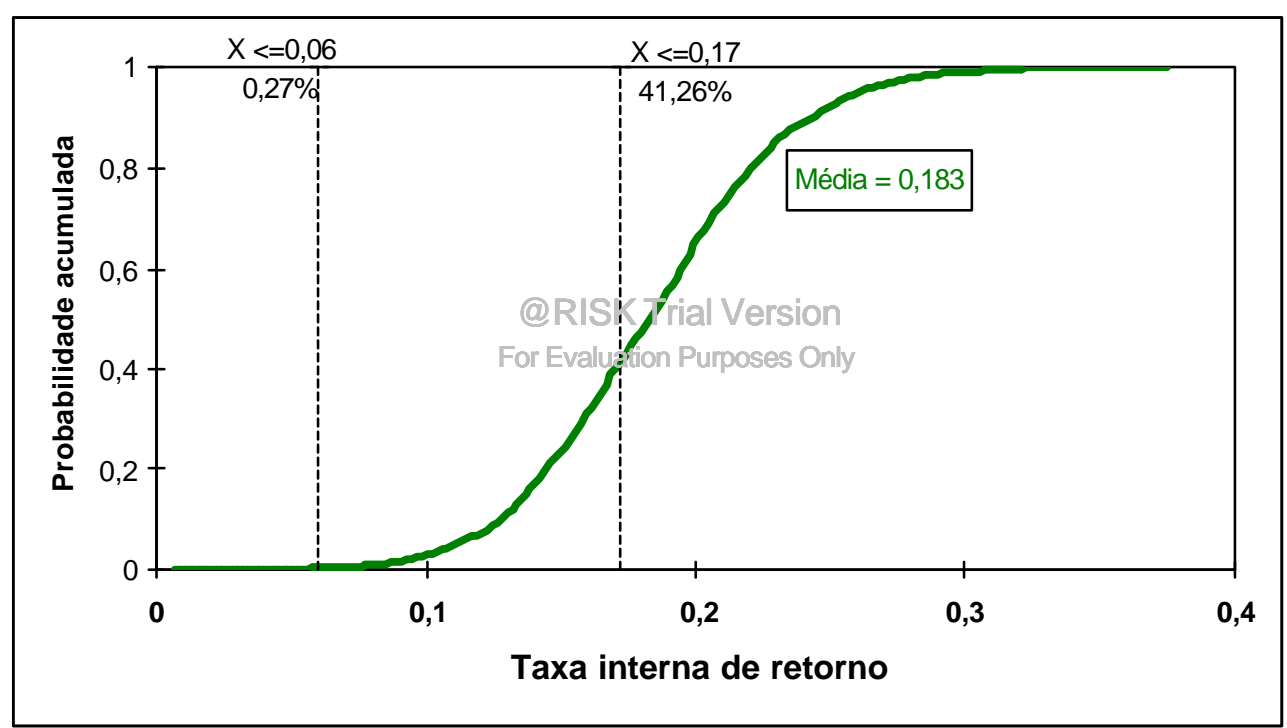

Figura 7 - Distribuição de probabilidade acumulada da taxa interna de retorno para o sistema não irrigado.

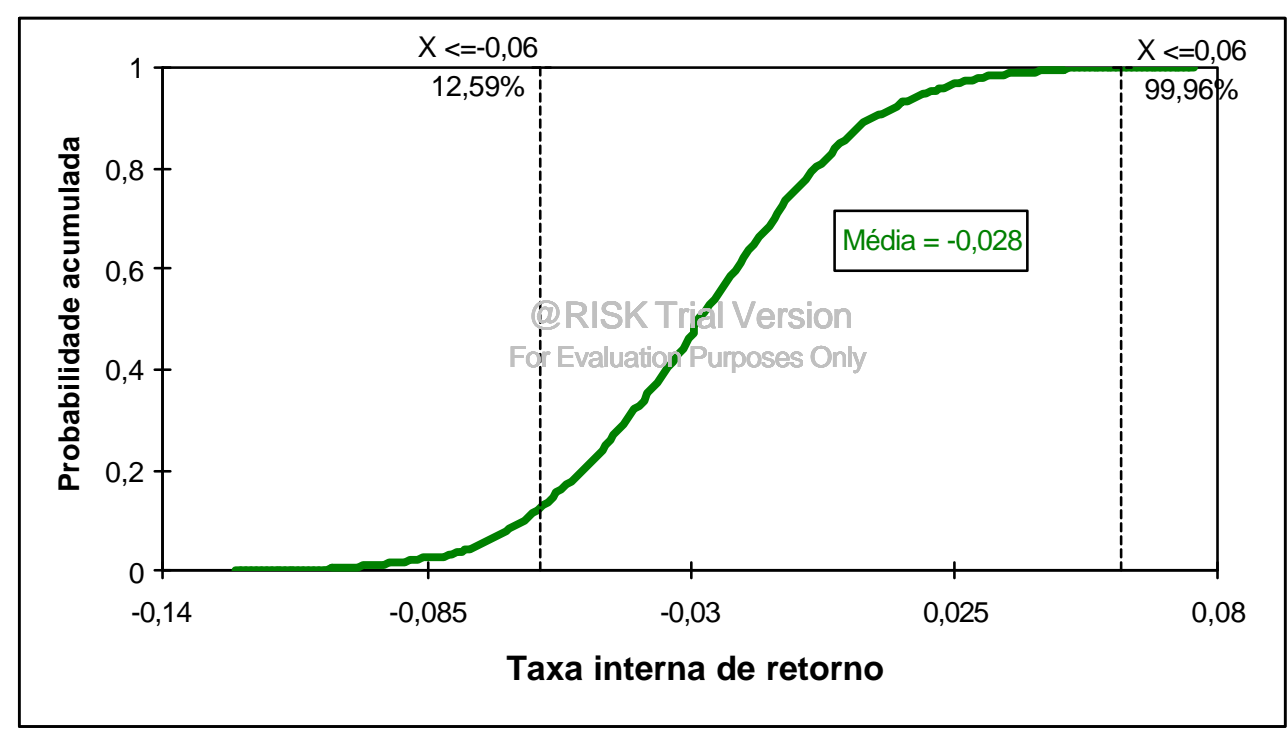

Figura 8 - Distribuição de probabilidade acumulada da taxa interna de retorno para o sistema irrigado.

Embora os resultados da análise de risco tenham apontado uma subestimativa dos indicadores de viabilidade econômica na análise determinística, as conclusões quanto à viabilidade econômica dos sistemas 
foram, de certa forma, reforçadas. O sistema sem irrigação se mostrou uma alternativa de investimento ainda mais atrativa, enquanto o sistema irrigado apresentou-se como uma alternativa de baixíssima probabilidade de viabilidade econômica.

\subsection{Conclusões}

Aquisição de animais e fertilizantes foram os principais componentes dos custos de produção, responsáveis respectivamente por $71,8 \%$ e $9,8 \%$ dos custos no sistema irrigado e $78,7 \%$ e $9,3 \%$ no sistema em sequeiro.

Os indicadores calculados através de simulação determinística apontaram inviabilidade econômica para o sistema irrigado. O sistema sem irrigação, por sua vez, mostrou-se viável e bastante atrativo como opção de investimento.

As principais variáveis responsáveis pelas variações no lucro líquido dos sistemas foram o custo dos animais de reposição e o preço de venda dos animais, sendo que o sistema irrigado foi mais susceptível a alterações de preço dessas variáveis.

A análise determinística subestimou o resultado dos indicadores de viabilidade econômica em ambos sistemas. Entretanto o sistema irrigado mostrourse de baixíssima probabilidade de viabilidade econômica, mesmo com a consideração dos riscos de preço e de produção. Para o sistema em sequeiro, a probabilidade de um resultado econômico desfavorável foi baixa. 


\section{CONCLUSÕES}

O experimento irrigado possibilitou desempenho animal médio de 0,492 $\mathrm{kg}$ GPD, enquanto no em sequeiro foi obtido $0,615 \mathrm{~kg}$ GPD. O desempenho animal médio dos experimentos, $0,553 \mathrm{~kg}$ GPD possibilitaria 0 abate dos animais em média aos 24 meses.

As taxas de lotação médias obtidas, 5,9 UA/ha no experimento irrigado e 5,6 UA/ha no não irrigado, não confirmaram o potencial da irrigação de pastagens no incremento da taxa de lotação. A irrigação só possibilitou incremento na taxa de lotação na transição entre os períodos de "seca" e "águas", de certa forma frustrando a expectativa de um grande diferencial de taxa de lotação entre os experimentos.

As produtividades animais obtidas, $1.628 \mathrm{~kg} \mathrm{PV/ha} \mathrm{no} \mathrm{experimento}$ irrigado e $1.672 \mathrm{~kg}$ PV/ha no em sequeiro, confirmaram o potencial de geração de elevadas produtividades por pastagens adubadas intensivamente. A diferença de produtividade animal entre os experimentos foi minimizada pelo maior desempenho animal do experimento sem irrigação em alguns períodos, demonstrando a importância desse componente na definição da produtividade quando as taxas de lotação são elevadas.

Os custos de aquisição de animais e de fertilizantes foram os principais componentes dos custos de produção, responsáveis por respectivamente $71,8 \%$ e $9,8 \%$ no sistema irrigado e $78,7 \%$ e $9,3 \%$ no sistema em sequeiro.

A simulação determinística apontou para o sistema sem irrigação resultados de custo operacional, custo total, custo por arroba produzida, custo por arroba total, respectivamente de $\mathrm{R} \$ 957,03$ por hectare, $\mathrm{R} \$ 6.698,41$ por hectare, $\mathrm{R} \$ 25,62$ por arroba e $\mathrm{R} \$ 44,92$ por arroba. Os valores correspondentes para o sistema irrigado foram respectivamente de $R \$ 1.339,83$ 
por hectare, $R \$ 7.466,37$ por hectare, $R \$ 38,81$ por arroba e $R \$ 50,03$ por arroba.

O lucro líquido obtido na análise sem consideração de risco no sistema sem irrigação foi de $\mathrm{R} \$ 574,90$ por hectare, com taxa de retorno sobre o ativo de $4,4 \%$. No sistema irrigado os valores correspondentes foram respectivamente de $\mathrm{R} \$-164,91$ e $-1,0 \%$.

Enquanto o sistema em sequeiro foi bastante atrativo como alternativa de investimento com taxa interna de retorno de 17,2\% na análise determinística, 0 sistema irrigado mostrou-se inviável economicamente com taxa interna de retorno de $-6,1 \%$.

A recuperação dos investimentos iniciais no sistema em sequeiro se daria em 3 anos, enquanto o irrigado seria incapaz de recuperar os investimentos iniciais realizados.

As principais variáveis responsáveis pelas variações no lucro líquido dos sistemas foram o custo de aquisição dos animais e o preço de venda dos animais. O sistema irrigado foi mais susceptível a alterações de preço dessas variáveis.

A análise determinística subestimou o resultado dos indicadores de viabilidade econômica em ambos sistemas. Entretanto o sistema irrigado mostrourse de baixíssima probabilidade de viabilidade econômica, mesmo com a consideração dos riscos de produção e de preço. Para o sistema em sequeiro, a probabilidade de um resultado de taxa interna de retorno abaixo de $6 \%$ a.a., custo de oportunidade do capital considerado, foi de apenas $0,27 \%$.

Novos trabalhos devem ser conduzidos com o objetivo de avaliar os resultados produtivos e econômicos de pastagens irrigadas em regiões com condições climáticas mais favoráveis ao desenvolvimento da planta forrageira, visto que, a região de Piracicaba apresenta claramente limitações climáticas proibitivas ao uso dessa técnica. 


\section{REFERÊNCIAS BIBLIOGRÁFICAS}

AGUIAR, A.P.A.; ALMEIDA, B.H.P.J.F.; AMARAL, G.C.; DATENA, J.L.F.; YOUNES, R.J.; COSTA, R.O.; MOTA, J.; VIVIAN, W.S.O. Viabilidade econômica da produção de carne em sistemas intensivos de pastagens na região do Cerrado. In: REUNIÃO ANUAL DA SOCIEDADE BRASILEIRA DE ZOOTECNIA, 38., Piracicaba, 2001. Anais. Piracicaba: SBZ, 2001a. p.14621464.

AGUIAR, A.P.A.; ALMEIDA, B.H.P.J.F.; REIS, G. S.; AMARAL, G.C.; DATENA, J.L.F.; YOUNES, R.J.; COSTA, R.O. Análise econômica de um sistema intensivo de produção de carne em pastagens dos capins tanzânia, Panicum maximum Jacq. cv tanzânia, e mombaça, Panicum maximum Jacq. cv mombaça, com animais cruzados, zebu europeu na região do cerrado (compact disc). In: REUNIÃO ANUAL DA SOCIEDADE BRASILEIRA DE ZOOTECNIA, 39., Recife, 2002. Anais. Recife: SBZ, 2002b.

AGUIAR, A.P.A.; AMARAL, G.C.; DATENA, J.L.F.; YOUNES, R.J.; COSTA, R.O.; MOTA, J.; VIVIAN, W.S.O. Produtividade de carne em sistemas intensivos nas pastagens de Mombaça, Tanzânia e Tifton-85 na região do Cerrado. In: REUNIÃO ANUAL DA SOCIEDADE BRASILEIRA DE ZOOTECNIA, 38., Piracicaba, 2001. Anais. Piracicaba: SBZ, 2001b. p.14611462.

AGUIAR, A.P.A.; REIS, G. S.; AMARAL, G.C.; DATENA, J.L.F.; YOUNES, R.J.; COSTA, R.O. Produtividade de carne em sistemas intensivos nas pastagens de Mombaça, Tanzânia e Tifton-85 na região do Cerrado (compact disc). In: REUNIÃO ANUAL DA SOCIEDADE BRASILEIRA DE ZOOTECNIA, 39., Recife, 2002. Anais. Recife: SBZ, 2002a. 
ALVIM, M. J.; BOTREL, M. A.; NOVELLY, P.E. Produção de gramíneas tropicais e temperadas, irrigadas na época da seca. Revista da Sociedade Brasileira de Zootecnia, v.15, n.5, p.384 - 392, 1986.

ALVIM, M. J.; MARTINS, C. E.; BOTREL, M. A.; SALVATI, J. A.; JACOB, M. A. M. Efeito da irrigação e da integração entre pastagens de setária e de azevém anual sobre a produção de leite. Pesquisa Agropecuária Brasileira, v.28, n.4, p.545-554, 1993.

ANDRADE JÚNIOR, A.S. Viabilidade da irrigação, sob risco climático e econômico, nas microrregiões de Teresina e litoral Piauiense. Piracicaba, 2000. 566p. Tese (Doutorado) - Escola Superior de Agricultura "Luiz de Queiroz", Universidade de São Paulo.

ANUÁRIO ESTATÍSTICO DO BRASIL-2000, v.60, p. 63, 2000.

ANUÁRIO ESTATíSTICO DO ESTADO DE SÃO PAULO - 1993, p.583-584, 1994.

ARRUDA, Z. J. A pecuária bovina de corte no Brasil e resultados econômicos de sistemas alternativos de produção. In: SIMPÓSIO SOBRE PECUÁRIA DE CORTE, 4., Piracicaba, 1996. Anais. Piracicaba: FEALQ, 1997. p.259273.

AZEVEDO FILHO, A.J.B. Análise econômica de projetos: "software" para situações deterministas e de risco envolvendo simulação. Piracicaba, 1988. 127p. Dissertação (Mestrado) - Escola Superior de Agricultura "Luiz de Queiroz", Universidade de São Paulo.

BALSALOBRE, M.A.A. Desempenho de vacas em lactação sob pastejo rotacionado de capim-elefante (Pennisetum purpureum Schum.). Piracicaba, 1996. 139p. Dissertação (Mestrado) - Escola Superior de Agricultura “Luiz de Queiroz", Universidade de São Paulo.

BALSALOBRE, M.A.A. Valor alimentar do capim tanzânia irrigado (Panicum maximum Jacq.). Piracicaba, 2002. 113p. Tese (Doutorado) - Escola Superior de Agricultura “Luiz de Queiroz”, Universidade de São Paulo. 
BALSALOBRE, M.A.A.; SANTOS, P.M.; BARROS, A.L.M. Inovações tecnológicas, investimentos financeiros e gestão de sistema de produção animal em pastagens. In: SIMPÓSIO SOBRE MANEJO DA PASTAGEM, 19., Piracicaba, 2002. Anais. Piracicaba: FEALQ, 2002. p.1 - 30.

BARBOSA, M.A.A.F.; NASCIMENTO JÚNIOR, D.; CECATO, U.; MORETTI, A.M.; GOMES, J.A.N; OLIVEIRA, F.C.L.; ALMEIDA JÚNIOR, J.; WESTPHAL, G; REGAZZI, A.J.; FONSECA, D.M. Desempenho de novilhos em capim tanzânia com diferentes ofertas de forragem. In: REUNIÃO ANUAL DA SOCIEDADE BRASILEIRA DE ZOOTECNIA, 38., Piracicaba, 2001. Anais. Piracicaba: SBZ, 2001. p.287-288.

BARIONE, L.G. Modelagem dinâmica e otimização metaheurística para apoio à tomada de decisões na recria e engorda de bovinos de corte. Piracicaba, 2002. 100p. Tese (Doutorado) - Escola Superior de Agricultura "Luiz de Queiroz", Universidade de São Paulo.

BOEHLJE, M.D.; EIDMAN, V.R. Farm management. New York: John Wiley, 1984. 806p.

BOLETIM PECUÁRIO SEMANAL. São Paulo, n. 489, fev. 2003. 10p.

BRUNELLI, G.M. Simulação do custo de produção de laranja no Estado de São Paulo. Piracicaba, 1990. 99p. Dissertação (Mestrado) - Escola Superior de Agricultura “Luiz de Queiroz”, Universidade de São Paulo.

CARO-COSTAS, R. Weight gains of cows fed on five grass pastures intensively managed in the humid hill region of Puerto Rico. Journal of Agriculture of University of Puerto Rico, v. 64, p.43-47, 1980.

CARVALHO, S. R.; SILVA, A. T.; COSTA, F. A. SOUTO; S. M. LUCAS, E. D. Influência da irrigação e da adubação em dois cultivares de capim elefante ( Pennisetum purpureum). Pesquisa Agropecuária Brasileira. Série Zootecnia, v.10, p.23-30, 1975.

CHACON, E.A.; STOBBS, T.H. Influence of progressive defoliation of grass sward on eating behavior of cattle. Australian Journal of Agricultural Research, v.27, p.709-727, 1976. 
CHACON, E.A.; STOBBS, T.H.; DALE, M.B. Influence of sward characteristics on grazing behavior and growth of hereford steers grazing tropical pastures. Australian Journal of Agricultural Research, v.29, p.89-102, 1978.

CHANDLER, J.V. Intensive grassland management in Puerto Rico. Revista Sociedade Brasileira de Zootecnia, v. 2, n. 2, p.173-215, 1973.

COORDENADORIA DE ASSISTÊNCIA TÉCNICA INTEGRAL. Levantamento censitário das unidades de produção agropecuária do Estado de São Paulo, 1999. http://www.cati.sp.gov.br (15 nov. 2002)

CORRÊA, L.A. Produção de gado de corte em pastagens adubadas. In: SIMPÓSIO GOIANO SOBRE PRODUÇÃO DE BOVINOS DE CORTE, Goiânia, 1999. Anais. Goiânia: CBNA, 1999, p.81-94.

CORSI, M.; SANTOS, P.M. Potencial de produção do Panicum maximum. $\mathbf{h}$ : SIMPÓSIO SOBRE MANEJO DA PASTAGEM, 12., Piracicaba, 1995. Anais. Piracicaba: FEALQ, 1995. p.249- 266.

EMPRESA BRASILEIRA DE PESQUISA AGROPECUÁRIA - Centro Nacional de Pesquisa de Solos. Sistema brasileiro de classificação de solos. Rio de Janeiro, EMBRAPA Solos, 1999. 412p.

ESTEVES, S.N. Custo de produção de carne utilizando pastagens adubadas. In: SIMPÓSIO SOBRE MANEJO E NUTRIÇÃO DE GADO DE CORTE, Goiânia, 2000. Anais. Goiânia: CBNA, 2000, p.25-40.

ESTRADA, R.D.; PALADINES, O. Evaluación econômica de la producción de carne en el trópico bajo pastoreo y com aplicación de nitrógeno. Turrialba, v.19, n. 4 p.247-254, 1979.

EUCLIDES, V.P.B.; EUCLIDES FILHO, K; COSTA, F.P.; FIGUEIREDO, G.R. Desempenho de novilhos F1s angus-nelore em pastagens de Brachiaria decumbens submetidos a diferentes regimes alimentares. Revista Brasileira de Zootecnia, v. 30, n. 2, p.470 - 481, 2001.

EUCLIDES FILHO, K. A pecuária de corte no Brasil: novos horizontes, novos desafios. Campo Grande: EMBRAPA, CNPGC, 1997. 28p. (EMBRAPA - CNPGC Documentos, 69). 
EUCLIDES FILHO, K; EUCLIDES, V.P.B.; FIGUEIREDO, G.R; BARBOSA, R.A. Eficiência bionutricional de animais nelore e seus mestiços com simental e aberdeen angus, em duas dietas. Revista Brasileira de Zootecnia, v. 30, n. 1, p.77-82, 2001.

FNP CONSUTORIA \& COMÉRCIO. ANUALPEC 2002: anuário da pecuária brasileira. São Paulo, 2002. 400p.

FRANKE, A.E.; DORFMAN, R. Viabilidade econômica da irrigação, sob condições de risco, em regiões de clima subtropical. I. Cultura do milho. Pesquisa Agropecuária Brasileira, v.33, n. 12, p.2003-2013, 1998.

FRIZZONE, J.A. Planejamento da irrigação: uma abordagem æ̀ decisões de investimento. Piracicaba: ESALQ, DER, 1999. 110p.

GHELFI FILHO, H. Efeito da irrigação sobre a produtividade do capim elefante (Pennisetum purpureum Schum.) variedade napier. Piracicaba, 1972. Tese (Doutorado) - Escola Superior de Agricultura "Luiz de Queiroz", Universidade de São Paulo.

GHELFI FILHO, H. Efeito da irrigação sobre o capim colonião Panicum maximum Jacq.). O Solo, v. 58, n.1, p.12-15, 1976.

GHELFI FILHO, H. Observação sobre o capim Brachiaria decumbens, irrigado na época de verão e inverno. Revista de Agricultura, Piracicaba, v. 53, n.3, p.167-170, 1978.

GOMIDE, J.A. Adubação de pastagens estabelecidas. In: SIMPÓSIO SOBRE MANEJO DA PASTAGEM, 7., Piracicaba, 1984. Anais. Piracicaba: FEALQ, 1984. p.33- 60 .

GONÇALVES, A.C.A. Variabilidade espacial de propriedades físicas do solo para fins de manejo da irrigação. Piracicaba, 1997. 118p. Tese (Doutorado) - Escola Superior de Agricultura "Luiz de Queiroz”, Universidade de São Paulo.

HALIM, R.A.; BUXTON, D.R.; HATTENDORF, M.J.; CARLSON, R.E. Waterstress effects on alfafa forage quality after adjustment for maturity differences. Agronomy Journal, v.81, p.189-194, 1989. 
HILLESHEIM, A. Fatores que afetam o consumo e perdas de capim elefante (Pennisetum purpureum Schum.) sob pastejo. Piracicaba, 1987. 94p. Dissertação (Mestrado). Escola Superior de Agricultura "Luiz de Queiroz", Universidade de São Paulo.

HIRSHFELD, H. Viabilidade técnicoeconômica de empreendimentos. São Paulo: Atlas, 1993. 211p.

INSTITUTO BRASILEIRO DE GEOGRAFIA E ESTATÍTICA. http://www.ibge.gov.br (15 nov. 2003).

INSTITUTO BRASILEIRO DO MEIO AMBIENTE E DOS RECURSOS NATURAIS RENOVÁVEIS. Desmatamentos na Amazônia Legal. Endereço http://www.ibama.gov.br (15 nov. 2002).

INSTITUTO DE ECONOMIA AGRÍCOLA. Preços de terra: valor de terra Nua, por categoria, escritório de desenvolvimento Rural (EDR) e estado de São Paulo, novembro de 2001 (R\$/ha). http://www.iea.sp.gov.br/out/iterra.htm (15 nov. 2002).

KNIGHT, F.H. Risco, incerteza e lucro. Rio de Janeiro: Expressão e Cultura, 1972. 385p.

LADEIRA, N.P.; SYKES, D.J.; DAKER, A.; GOMIDE, J.A. Estudos sobre a produção e irrigação dos capins pangola, sempre verde e gordura, durante o ano de 1965. Revista Ceres, v. 13, n. 74, p.105-116, 1966.

LOURENÇO, L.F.; COELHO, R.D.; SORIA, L.G.T.; PINHEIRO, V.D.; CORSI, M. Coeficiente de cultura $(\mathrm{Kc})$ do capim tanzânia (Panicum maximum Jacq.) irrigado por pivô central. In: REUNIÃO ANUAL DA SOCIEDADE BRASILEIRA DE ZOOTECNIA, 38., Piracicaba, 2001. Anais. Piracicaba: SBZ, 2001. p.316 - 317.

LUGÃO, S.M.B. Produção de forragem e desempenho animal em pastagens de Panicum maximum Jacq. (acesso BRA-006998) adubadas com nitrogênio na região noroeste do Estado do Paraná. Jaboticabal, 2001. 151p. Tese (Doutorado) - Faculdade de Ciências Agrárias, Universidade Estadual Paulista "Júlio de Mesquita Filho". 
MALDONADO, H.; DAHER, R.F.; PEREIRA, A.V.; FERNANDES, A.M.; SOARES, C.S.; SILVA, L.C.C.; BORGES, A. Efeito da irrigação na produção de matéria seca do capim-elefante (Pennisetum purpureum Schum.) em Campos dos Goytacazes, RJ. In: REUNIÃO ANUAL DA SOCIEDADE BRASILEIRA DE ZOOTECNIA, 34., Juiz de Fora, 1997. Anais. Juiz de Fora: SBZ, 1997. p.216-217.

MARCELINO, K.R.A.; LEITE, G.G.; VILELA, L.; DIOGO, J.M.S.; GUERRA, A.F. Efeito da adubação nitrogenada e da irrigação sobre a produtividade e índice de área foliar de duas gramíneas cultivadas no cerrado. In: REUNIÃO ANUAL DA SOCIEDADE BRASILEIRA DE ZOOTECNIA, 38., Piracicaba, 2001. Anais. Piracicaba: SBZ, 2001. p.230-231.

MATSUMOTO, E.; ISEPON, O.J.; BASTOS, J.F.P.; MELLO, S.Q.S. Produção de matéria seca de cinco cultivares de Panicum maximum Jacq. submetidos à irrigação (compact disk). In: REUNIÃO ANUAL DA SOCIEDADE BRASILEIRA DE ZOOTECNIA, 39., Recife, 2002. Anais. Recife: SBZ, 2002.

MATTOS, Z.P. B. Contabilidade financeira rural. São Paulo: Atlas, 1999. $196 \mathrm{p}$.

MELO, J.F. Custos da irrigação por aspersão em Minas Gerais. Viçosa, 1993. 147p. Dissertação (Mestrado) - Universidade Federal de Viçosa.

MÜLLER, M. S. Desempenho de Panicum maximum (cv. Mombaça) em Pastejo Rotacionado, sob Sistema de Irrigação por Pivô Central, na Região de Cerrado. Piracicaba, 2000. 101p. Dissertação (Mestrado) - Escola Superior de Agricultura "Luiz de Queiroz", Universidade de São Paulo.

NORONHA, J.F. Projetos agropecuários: administração financeira, orçamentação e avaliação econômica. Piracicaba: FEALQ, 1981. 274p.

OLIVEIRA, R.F.M.; FONTE, C.A.A.; SILVA, J.F.C. Consumo e digestibilidade de dietas com duas proporções de concentrados fornecidas a bovinos de três grupos genéticos. Revista da Sociedade Brasileira de Zootecnia, v. 20, n. 5, p.513-521, 1991. 
PALISADE CORPORATION. @Risk: risk analysis and simulation add - in for Microsoft Excel. New Field, 2002. 511p.

PENATI, M.A. Estudo do desempenho animal e produção do capim tanzânia (Panicum maximum Jacq.) em um sistema rotacionado sob irrigação em três níveis de resíduo pós-pastejo. Piracicaba, 2002. 117p. Tese (Doutorado) Escola Superior de Agricultura "Luiz de Queiroz", Universidade de São Paulo.

PENATI, M.A.; CORSI, M.; DIAS, C.T.S.; MAYA, F.L.A. Efeito do número de amostras e da relação dimensão-formato da moldura sobre o coeficiente de variação na determinação da massa de forragem em pastagens de capim tanzânia. In: REUNIÃO ANUAL DA SOCIEDADE BRASILEIRA DE ZOOTECNIA, 38., Piracicaba, 2001. Anais. Piracicaba: SBZ, 2001. p.46-47.

PERES, F.C.; MATTOS, Z.P.B. Simulação como auxílio à decisão de confinar bovinos de corte. In: SIMPÓSIO DA SOCIEDADE BRASILEIRA DE ZOOTECNIA: BOVINOCULTURA DE CORTE, 2, Campinas, 1990. Anais. Piracicaba: FEALQ, 1990. p. 97-108.

PINHEIRO, V.D. Viabilidade econômica da irrigação de pastagens de capim tanzânia em diferentes regiões do Brasil. Piracicaba, 2002. 85p. Dissertação (Mestrado) - Escola Superior de Agricultura "Luiz de Queiroz", Universidade de São Paulo.

ROSS, S.A.; WESTERFIELD, R.W.; JORDAN, B.D. Princípios de administração financeira. São Paulo: Atlas, 1998. 432p.

SALLES, P.A.A.; GONÇALVES, J.O.N. Quantidade ótima econômica de nitrogênio usado em capim pangola e sua determinação pelo preço relativo atualizado do fator. Pesquisa Agropecuária Brasieira, v.17, n. 8 p.11051111, 1982.

SNAYDON, R.W. The effect of total water supply, and of frequency of application, upon lucerne. Australian Journal of Agricultural Research, v.23, p.253-256, 1972. 
SOLER, C.T; MEIRELES, E.J.; COELHO, R.D. Viabilidade econômica da irrigação em café na região de Franca-SP (compact disk). In: CONGRESSO BRASILEIRO DE ENGENHARIA AGRíCOLA, 28., Pelotas, 1999. Anais. Pelotas: UFPel, 1999.

SOUSA, S.A.V. Programa computacional para a simulação da ocorrência de veranicos e queda de produção. Piracicaba, 1999. 124p. Tese (Doutorado) - Escola Superior de Agricultura "Luiz de Queiroz", Universidade de São Paulo.

SOUZA, J.L.M. Modelo para a análise de risco econômico aplicado ao planejamento de projetos de irrigação para a cul tura do cafeeiro. Piracicaba, 2001. 253p. Tese (Doutorado) - Escola Superior de Agricultura "Luiz de Queiroz", Universidade de São Paulo.

STATISTICAL ANALYSIS SYSTEM. SAS: user's guide statistics: version 6.10 edition. Cary, 1995. 956p.

STOBBS, T.H. The effect of plant structure on the intake of tropical pastures -1 . Variation in the bite size of grazing cattle. Australian Journal of Agricultural Research, v.24, p.809-819, 1973a.

STOBBS, T.H. The effect of plant structure on the intake of tropical pastures- II. Differences in sward structure, nutritive value, and bite size of animals grazing Setaria anceps and Chloris gayana at various stages of growth. Australian Journal of Agricultural Research, v.24, p.821-829, 1973b.

TAKITANE, I.C. Custo de produção da borracha e análise de rentabilidade em condições de risco no Planalto Paulista, SP e no Triângulo Mineiro, MG. Piracicaba, 1988. 119p. Dissertação (Mestrado) - Escola Superior de Agricultura "Luiz de Queiroz", Universidade de São Paulo.

THORNTHWAITE, C.W.; MATHER, J.R. The water balance. Centerton: DIT, 1955. 104p. 
TOSI, P. Estabelecimento de parâmetros agronômicos para o manejo e eficiência de utilização de Panicum maximum Jacq. cv. Tanzânia-1 sob pastejo rotacionado. Piracicaba, 1999. 103p. Dissertação (mestrado) Escola Superior de Agricultura "Luiz de Queiroz", Universidade de São Paulo.

TURRA, F.E. Análise de diferentes métodos de cálculo de custos de produção na agricultura brasileira. Piracicaba, 1990. 134p. Dissertação (mestrado) Escola Superior de Agricultura "Luiz de Queiroz", Universidade de São Paulo.

VILELA, H.; VILELA, D.; BARBOSA, F.A.; BENEDETTI, E.; NOGUEIRA, A.C. Irrigação do capim elefante paraíso (compact disk). In: REUNIÃO ANUAL DA SOCIEDADE BRASILEIRA DE ZOOTECNIA, 39., Recife, 2002. Anais. Recife: SBZ, 2002.

WILSON, J.R. Effects of water stress on in vitro dry matter digestibility and chemical composition of herbage tropical pasture species. Australian Journal of Agricultural Research, v.34, p.377-390, 1983.

WILSON, J.R.; LUDLOW, M.M.; FISHER, M.J.; SCHULZE, E.D. Adaptation to water stress of the leaf water relations of four tropical species. Australian Journal of Plant Physiology, v.7, p.207-220, 1980.

WILSON, J.R.; NG, T.T. Influence of water stress on parameters associated with herbage quality of Panicum maximum var. trichoglume. Australian Journal of Agricultural Research, v.26, p.127-136, 1975. 